Article

\title{
Co-Cr-0 mixed oxides for low-temperature total oxidation of propane: Structural effects, kinetics, and spectroscopic investigation
}

\author{
Wen-Min Liao, Pei-Pei Zhao, Bing-Heng Cen, Ai-Ping Jia, Ji-Qing Lu *, Meng-Fei Luo \# \\ Key Laboratory of the Ministry of Education for Advanced Catalysis Materials, Institute of Physical Chemistry, Zhejiang Normal University, Jinhua 321004, \\ Zhejiang, China
}

A R T I C L E I N F

Article history:

Received 7 July 2019

Accepted 2 August 2019

Published 5 March 2020

\section{Keywords:}

Propane combustion

Co-Cr mixed oxides

Reducibility

Surface acidity

Kinetics

\begin{abstract}
A B S T R A C T
A series of $\mathrm{Co}-\mathrm{Cr}-\mathrm{O}$ mixed oxides with different $\mathrm{Co} / \mathrm{Cr}$ molar ratios are synthesized and tested for the total oxidation of propane. The reaction behaviors are closely related to the structural features of the mixed oxides. The catalyst with a $\mathrm{Co} / \mathrm{Cr}$ molar ratio of $1: 2(1 \mathrm{Co} 2 \mathrm{Cr})$ and a spinel structure has the best activity (with a reaction rate of $1.38 \mu \mathrm{mol} \mathrm{g}^{-1} \mathrm{~s}^{-1}$ at $250{ }^{\circ} \mathrm{C}$ ), which is attributed to the synergistic roles of its high surface acidity and good low-temperature reducibility, as evidenced by the temperature-programmed desorption of ammonia, reduction of hydrogen, and surface reaction of propane. Kinetic study shows that the reaction orders of propane and oxygen on the $1 \mathrm{Co} 2 \mathrm{Cr}$ catalyst $(0.58 \pm 0.03$ and $0.34 \pm 0.05$, respectively) are lower than those on the $2 \mathrm{Co} 1 \mathrm{Cr}$ catalyst $(0.77 \pm$ 0.02 and $0.98 \pm 0.16$, respectively) and $1 \operatorname{Co} 5 \operatorname{Cr}(0.66 \pm 0.05$ and $1.30 \pm 0.11$, respectively), indicating that the coverages of propane and oxygen on $1 \mathrm{Co} 2 \mathrm{Cr}$ are higher than those on the other catalysts due to its higher surface acidity and higher reducibility. In addition, in-situ diffuse reflectance infrared spectroscopic investigation reveals that the main surface species on $1 \mathrm{Co} 2 \mathrm{Cr}$ during the reaction are polydentate carbonate species, which accumulate on the surface at low temperatures $\left(<250{ }^{\circ} \mathrm{C}\right)$ but decompose at relatively high temperatures.
\end{abstract}

(C) 2020, Dalian Institute of Chemical Physics, Chinese Academy of Sciences. Published by Elsevier B.V. All rights reserved.

\section{Introduction}

Alkanes are one of the major volatile organic compounds (VOCs) that are massively produced from automobile exhaust and various industrial processes, such as coal processing, petroleum refining, and natural gas processing [1,2]. Increasingly stringent environmental legislation urges the development of efficient technologies for the abatement of VOCs. Catalytic total oxidation (catalytic combustion) has been considered a promising strategy due to its advantages, such as low light-off temperature, low energy consumption, high purification efficiency, and no secondary pollution. For the catalytic combustion of light alkanes, e.g., methane and propane, noble metals such as Pt and Pd are very effective as catalysts [3-10]. However, the high cost and vulnerability to poisoning have become the major limitations to their commercial applications. Transition metal oxides are appealing alternatives due to their low cost, resistance to toxicity, and high thermal stability. Admittedly, it has been reported that various transition metal oxides (or mixed oxides) such as $\mathrm{Cu}, \mathrm{Mn}, \mathrm{Co}, \mathrm{Fe}$, and $\mathrm{Ni}$ oxides are active in the catalytic combustion of propane [11-22].

Among transition metal oxides, cobalt oxides $\left(\mathrm{CO}_{3} \mathrm{O}_{4}\right)$ have attracted much attention due to their high activity in propane combustion. For example, porous $\mathrm{Co}_{3} \mathrm{O}_{4}$ oxides prepared via an

\footnotetext{
* Corresponding author. Tel: +86-579-82287325; Fax: +86-579-82282595; E-mail: jiqinglu@zjnu.cn

\# Corresponding author. Tel: +86-579-82287325; Fax: +86-579-82282595; E-mail: mengfeiluo@zjnu.cn

This work was financially supported by the National Natural Science Foundation of China $(21773212,21872124)$.

DOI: S1872-2067(19)63480-7 | http://www.sciencedirect.com/science/journal/18722067 | Chin. J. Catal., Vol. 41, No. 3, March 2020
} 
aqueous precipitation method showed a reaction rate of 1.69 $\mu \mathrm{mol} \mathrm{g} \mathrm{g}^{-1} \mathrm{~s}^{-1}$ at $200{ }^{\circ} \mathrm{C}$ for propane combustion [15], and the high activity was attributed to the improved accessibility of the reactants to the surface of the catalyst, which exhibited a large porosity (up to $76 \%$ ). The activity could be further improved by the addition of a secondary metal. A Ni-doped nano-array $\mathrm{Co}_{3} \mathrm{O}_{4}$ catalyst $\left(\mathrm{Ni}_{0.27} \mathrm{Co}_{2.73} \mathrm{O}_{4}\right)$ afforded a reaction rate of 5.58 $\mu \mathrm{mol} \mathrm{g} \mathrm{g}^{-1} \mathrm{~s}^{-1}$ at $250{ }^{\circ} \mathrm{C}$, which was higher than that afforded by the pure $\mathrm{Co}_{3} \mathrm{O}_{4}$ (c.a. $3.00 \mu \mathrm{mol} \mathrm{g}-1 \mathrm{~s}^{-1}$ at $250{ }^{\circ} \mathrm{C}$ ). The promoting role of $\mathrm{Ni}$ was ascribed to the promoted surface lattice oxygen activity [16]. Faure and Alphonse [23] also reported that a $\mathrm{Co}_{2.3} \mathrm{Mn}_{0.7} \mathrm{O}_{4}$ spinel oxide exhibited better activity than the pure cobalt oxide for both $\mathrm{CO}$ and propane oxidation, due to its high surface area (up to $250 \mathrm{~m}^{2} \mathrm{~g}^{-1}$ ) and high Co concentration. Therefore, the formation of Co-M-O (M is a secondary metal) mixed oxides appears to be a promising approach to improving the catalytic activity toward propane combustion. In this sense, Co-Cr-O mixed oxides might be effective because such a combination is very effective in oxidation reactions, such as the catalytic combustion of methane [24] and chlorinated VOCs (CVOCs) [25,26]. The enhanced activities of these Co-Cr-O mixed oxides could be attributed to the Cr-related high-surface acidity and high reducibility of the oxygen species, which are also two crucial parameters in VOCs combustion [27-29].

In this work, a series of $\mathrm{Co}-\mathrm{Cr}-\mathrm{O}$ mixed oxides with different $\mathrm{Co} / \mathrm{Cr}$ molar ratios were synthesized and tested for the total oxidation of propane. Detailed characterizations were conducted to clarify the structural and surface properties of these catalysts, which were further correlated to their performances. Moreover, kinetic investigation and in-situ spectroscopic studies were performed to interpret the different behaviors and possible reaction pathways on the catalysts, as well as the surface species. It was found that the catalyst properties were strongly dependent on the $\mathrm{Co} / \mathrm{Cr}$ molar ratio, which consequently influenced the catalytic behaviors profoundly.

\section{Experimental}

\subsection{Catalyst preparation}

The Co-Cr-O mixed oxides with different $\mathrm{Co} / \mathrm{Cr}$ molar ratios were prepared by a sol-gel method. Considering the mixed oxide with a Co/Cr molar ratio of $1: 2$ as an example, $0.05 \mathrm{~mol}$ of $\mathrm{Co}\left(\mathrm{NO}_{3}\right)_{2} \cdot 6 \mathrm{H}_{2} \mathrm{O}, 0.10 \mathrm{~mol}$ of $\mathrm{Cr}\left(\mathrm{NO}_{3}\right)_{3} \cdot 9 \mathrm{H}_{2} \mathrm{O}$, and $0.30 \mathrm{~mol}$ of citric acid were dissolved in $50 \mathrm{~mL}$ of deionized $\mathrm{H}_{2} \mathrm{O}$. The solution was stirred at $80^{\circ} \mathrm{C}$ for $6 \mathrm{~h}$ to obtain a gel, which was dried at $100{ }^{\circ} \mathrm{C}$ for $24 \mathrm{~h}$. Finally, the solid substance was calcined at $600{ }^{\circ} \mathrm{C}$ in static air for $4 \mathrm{~h}$. The resulting catalyst was denoted as $1 \mathrm{Co} 2 \mathrm{Cr}$. Other catalysts were prepared in a similar manner and were denoted as $x \mathrm{CoyCr}$, where $x / y$ was the nominal $\mathrm{Co} / \mathrm{Cr}$ molar ratio in the catalyst. The pure cobalt oxide and chromium oxide were denoted as $\mathrm{CoO}_{x}$ and $\mathrm{CrO}_{x}$, respectively.

\subsection{Catalyst characterizations}

The specific surface areas of the catalysts were measured by $\mathrm{N}_{2}$ absorption at $77 \mathrm{~K}$ on a BK200C surface area analyzer. The catalysts were pretreated under vacuum at $150{ }^{\circ} \mathrm{C}$ for $4 \mathrm{~h}$. The Brunauer-Emmet-Teller (BET) method was employed to calculate the specific area.

The exact $\mathrm{Co}$ and $\mathrm{Cr}$ contents in the catalysts were determined by X-ray fluorescence (XRF) spectroscopy using an ARL ADVANT'X Intelli Power 4200 scanning X-ray fluorescence spectrometer. The result was analyzed using a UniQuant non-standard sample quantitative analysis software.

The crystalline structures of the catalysts were determined by X-ray diffraction, which was conducted with a Bruker X-ray diffractometer (XRD, D8 Advance type) using $\mathrm{Cu} K_{\alpha}$ radiation at $40 \mathrm{kV}$ and $40 \mathrm{~mA}$. The scanning $2 \theta$ range was $20^{\circ}-70^{\circ}$, with a step size of $0.02^{\circ} \mathrm{s}^{-1}$. The crystallite sizes and lattice parameters of the catalysts were analyzed using the JADE 6.0 software.

The Raman spectra of the catalysts were collected on a Renishaw Invia confocal microprobe under ambient condition (laser power = $3 \mathrm{~mW}$; dwell time $=30 \mathrm{~s}$; number of scans $=30$; resolution $=1 \mathrm{~cm}^{-1}$ ). The wavelength of the excitation laser was $325 \mathrm{~nm}$. Prior to the measurement, the sample was heated by an infrared lamp $\left(80^{\circ} \mathrm{C}, 15 \mathrm{~min}\right)$ to remove the water in the sample.

The reducibility of the catalyst was measured by the hydrogen-temperature-programmed reduction $\left(\mathrm{H}_{2}-\mathrm{TPR}\right)$ technique, which was performed on a home-made apparatus. Forty milligrams of the catalyst was loaded in the reactor and was pretreated at $300{ }^{\circ} \mathrm{C}$ for $1 \mathrm{~h}$ in a flow of $10 \mathrm{vol} \% \mathrm{O}_{2}+90$ vol\% $\mathrm{N}_{2}$ (30 mL min-1). After the sample was cooled to room temperature, it was heated in a flow of $5 \mathrm{vol} \% \mathrm{H}_{2}+95 \mathrm{vol} \% \mathrm{~N}_{2}(30 \mathrm{~mL}$ $\mathrm{min}^{-1}$ ) to $700{ }^{\circ} \mathrm{C}$ at a ramping rate of $10{ }^{\circ} \mathrm{C} \mathrm{min}-1$. The signal was recorded by a thermal conductivity detector (TCD), and the $\mathrm{H}_{2}$ consumption was calibrated by the reduction of a known amount of $\mathrm{CuO}$ powder.

The surface acidity of the catalyst was measured by ammonia-temperature-programmed desorption $\left(\mathrm{NH}_{3}-\mathrm{TPD}\right)$. In a typical measurement, $300 \mathrm{mg}$ of the catalyst was loaded in the home-made reactor and pretreated at $300{ }^{\circ} \mathrm{C}$ for $1 \mathrm{~h}$ in a flow of 10 vol $\% \mathrm{O}_{2}+90$ vol\% $\mathrm{N}_{2}$ (30 $\mathrm{mL} \mathrm{min}^{-1}$ ). Subsequently, it was cooled to $100{ }^{\circ} \mathrm{C}$ and exposed to a flow of pure $\mathrm{NH}_{3}(30 \mathrm{~mL}$ $\left.\min ^{-1}\right)$ for $1 \mathrm{~h}$. After the catalyst was purged by pure $\mathrm{N}_{2}(30 \mathrm{~mL}$ $\left.\mathrm{min}^{-1}\right)$ at $100^{\circ} \mathrm{C}$ for $30 \mathrm{~min}$, it was heated to $600{ }^{\circ} \mathrm{C}$ at a ramping rate of $10{ }^{\circ} \mathrm{C} \mathrm{min}^{-1}$. The signal of the desorbed $\mathrm{NH}_{3}$ was recorded by mass spectrometry (MS, Hiden, QIC-20) at $m / e=$ 17.

The oxidation states of the elements in the catalysts were determined by X-ray photoelectron spectroscopy (XPS, ESCALAB 250Xi). Monochromated Al $K_{\alpha}$ served as the X-ray source (1486.6 eV). The binding energy of each element in the catalyst was corrected by the $\mathrm{C} 1 \mathrm{~s}$ line $\left(E_{\mathrm{Cls}}=284.6 \mathrm{eV}\right)$.

The temperature-programmed surface reaction of propane ( $\mathrm{C}_{3} \mathrm{H}_{8}$-TPSR) was carried out in the home-made apparatus. The catalyst $(300 \mathrm{mg}$ ) loaded in a quartz tubular reactor was pretreated at $300{ }^{\circ} \mathrm{C}$ for $1 \mathrm{~h}$ in a flow of $10 \mathrm{vol} \% \mathrm{O}_{2}+90 \mathrm{vol} \%$ $\mathrm{N}_{2}$ (30 mL min-1). After the catalyst was cooled to room temperature, it was exposed to a flow of 5 vol\% $\mathrm{C}_{3} \mathrm{H}_{8}+95$ vol\% $\mathrm{N}_{2}$ (30 mL min-1) and heated to $600{ }^{\circ} \mathrm{C}$ at a ramping rate of $10{ }^{\circ} \mathrm{C}$ min $^{-1}$. The outlet signals of $\mathrm{C}_{3} \mathrm{H}_{8}, \mathrm{CO}_{2}$, and $\mathrm{H}_{2} \mathrm{O}$ were recorded by mass spectrometry (MS, Hiden, QIC-20) at $m / e=27,44$, and 
18 , respectively.

The in-situ diffuse reflectance infrared spectroscopy (DRIFTS) of propane oxidation was performed on a Thermal-Fischer Nicolet iS50 FTIR spectrometer equipped with an MCT detector. A certain amount of the catalyst was loaded in a PIKE DRIFT accessory and was pretreated in 10 vol\% $\mathrm{O}_{2}+90$ vol\% $\mathrm{N}_{2}\left(30 \mathrm{~mL} \mathrm{~min}^{-1}\right)$ at $450{ }^{\circ} \mathrm{C}$ for $30 \mathrm{~min}$, followed by $\mathrm{N}_{2}$ purge for another $30 \mathrm{~min}$. Thereafter, it was cooled to room temperature in a $\mathrm{N}_{2}$ flow ( $30 \mathrm{~mL} \mathrm{~min}^{-1}$ ), and the background spectra were recorded at different temperatures. Afterward, a mixture flow of 0.2 vol\% $\mathrm{C}_{3} \mathrm{H}_{8}+2$ vol $\% \mathrm{O}_{2}$ balanced with $\mathrm{N}_{2}$ (30 $\mathrm{mL} \mathrm{min}^{-1}$ ) was introduced, and the catalyst was heated to 450 ${ }^{\circ} \mathrm{C}$ at a ramping rate of $10^{\circ} \mathrm{C} \mathrm{min}-1$. The spectra were collected at certain temperatures, which were subtracted with corresponding backgrounds.

\subsection{Catalyst activity testing and kinetic investigation}

The performance of the catalysts toward the total oxidation of propane was tested in a fixed-bed micro-reactor. Fifty milligrams of the catalyst (60-80 mesh) was diluted with $50 \mathrm{mg}$ of quartz sand of the same size and loaded in a tubular quartz reactor (i.d. $=6 \mathrm{~mm}$ ). A thermal couple was placed in the middle of the catalyst bed to monitor the reaction temperature. A gas mixture consisting of $0.2 \mathrm{vol} \% \mathrm{C}_{3} \mathrm{H}_{8}$ and $2 \mathrm{vol} \% \mathrm{O}_{2}$ (balanced by $\mathrm{N}_{2}$ ) with a total flow rate of $67 \mathrm{~mL} \mathrm{~min}^{-1}$ (GHSV = $80000 \mathrm{~mL} \mathrm{~g}^{-1} \mathrm{~h}^{-1}$ ) was employed. The outlet gas was analyzed using a gas chromatograph (Shimadzu GC-2014) equipped with a flame-ionized detector (FID) and capillary column (DB-WAX, $30 \mathrm{~m} \times 0.25 \mathrm{~mm} \times 0.25 \mu \mathrm{m}$ ). The conversion of propane was calculated using the following equation:

$$
X_{\mathrm{C} 3 \mathrm{H} 8}(\%)=\left(\left[\mathrm{C}_{3} \mathrm{H}_{8}\right]_{\text {in }}-\left[\mathrm{C}_{3} \mathrm{H}_{8}\right]_{\text {out }}\right) \times 100 \% /\left[\mathrm{C}_{3} \mathrm{H}_{8}\right]_{\text {in }}
$$

where $X\left(\mathrm{C}_{3} \mathrm{H}_{8}\right)$ is the conversion of propane; $\left[\mathrm{C}_{3} \mathrm{H}_{8}\right]_{\text {in }}$ and $\left[\mathrm{C}_{3} \mathrm{H}_{8}\right]_{\text {out }}$ are the concentrations of propane in the inlet and outlet, respectively.

The reaction behaviors of the catalysts were also tested under wet reaction conditions, where 2.5 vol\% of water vapor was introduced by passing the reactants through a water bubbler at $0{ }^{\circ} \mathrm{C}$.

Kinetic studies of the total oxidation of propane over some

\section{Table 1}

Specific surface areas, actual $\mathrm{Co} / \mathrm{Cr}$ molar ratios, crystallite sizes, and lattice parameters of various $x \operatorname{Coy} C r$ catalysts.

\begin{tabular}{lcccc}
\hline Catalyst & $\begin{array}{c}\text { A } \\
/ \mathrm{mET}^{2} \mathrm{~g}^{-1}\end{array}$ & $\begin{array}{c}\text { Actual Co/Cr } \\
\text { molar ratio }\end{array}$ & $\begin{array}{c}\text { Crystallite } \\
\text { size } \\
/ \mathrm{nm}\end{array}$ & $\begin{array}{c}\text { Lattice parameter } \\
/ \mathrm{nm}\end{array}$ \\
\hline $\mathrm{CoO}_{x}$ & 2 & - & $>100$ & $0.8082 / 0.8082 / 0.8082$ \\
$5 \mathrm{Co} 1 \mathrm{Cr}$ & 6 & $4.89 / 1$ & 36.9 & $0.8085 / 0.8085 / 0.8085$ \\
$2 \mathrm{Co} 1 \mathrm{Cr}$ & 15 & $2.05 / 1$ & $9.0^{\mathrm{a}}$ & $0.8101 / 0.8101 / 0.8101^{\mathrm{a}}$ \\
& & & $20.7^{\mathrm{b}}$ & $0.8235 / 0.8235 / 0.8235^{\mathrm{b}}$ \\
$1 \mathrm{Co} 1 \mathrm{Cr}$ & 20 & $0.95 / 1$ & 22.6 & $0.8273 / 0.8273 / 0.8273$ \\
$1 \mathrm{Co} 2 \mathrm{Cr}$ & 86 & $1 / 2.13$ & 8.0 & $0.8327 / 0.8327 / 0.8327$ \\
$1 \mathrm{Co} \mathrm{Cr}$ & 38 & $1 / 4.78$ & $14.8^{\mathrm{c}}$ & $0.4953 / 0.4953 / 1.35744^{\mathrm{c}}$ \\
& & & $15.7^{\mathrm{d}}$ & $0.8331 / 0.8331 / 0.8331^{\mathrm{d}}$ \\
$\mathrm{CrO}_{x}$ & 27 & - & 18.8 & $0.4960 / 0.4960 / 1.3605$ \\
\hline
\end{tabular}

a Spinel $\mathrm{Co}_{3} \mathrm{O}_{4}$ (JCPDS No. 42-1467); ${ }^{\mathrm{b}} \mathrm{Co}_{2} \mathrm{CrO}_{4}$ (JCPDS No. 24-0326);

${ }^{\mathrm{c}} \mathrm{Cr}_{2} \mathrm{O}_{2.4}$ (JCPDS No. 51-0959); d spinel $\mathrm{CoCr}_{2} \mathrm{O}_{4}$ (JCPDS No. 22-1084). representative catalysts were conducted under differential reaction modes (with propane conversion less than 15\%). The absence of mass and heat transfer limitations were verified. For example, the Weisz-Prater criterion $\left(C_{\mathrm{WP}}\right)$ was used for internal diffusion; the Mears criterion $\left(C_{\mathrm{M}}\right)$ was used for external diffusion, and the Mears' criterion $\left(C_{\mathrm{M}}\right)$ was used for heat transfer (see Supporting Information for detailed calculations). The reaction orders of propane and oxygen were measured at propane partial pressures in the range of $0.202-0.505 \mathrm{kPa}$ and oxygen partial pressures in the range of 4.04-9.09 $\mathrm{kPa}$.

\section{Results and discussion}

\subsection{General characterizations of the catalysts}

The synthesized catalysts have significantly different specific surface areas, depending on their compositions. As shown in Table 1, the pure $\mathrm{CoO}_{x}$ has a very low surface area $\left(2 \mathrm{~m}^{2} \mathrm{~g}^{-1}\right)$, and the surface area gradually increases with the addition of $\mathrm{Cr}$ in the samples. The $1 \mathrm{Co} 2 \mathrm{Cr}$ mixed oxide has the largest surface area $\left(86 \mathrm{~m}^{2} \mathrm{~g}^{-1}\right)$; however, further addition of $\mathrm{Cr}$ results in a decline in the surface area, as the pure $\mathrm{CrO}_{x}$ has a surface area of $27 \mathrm{~m}^{2} \mathrm{~g}^{-1}$. Furthermore, the actual $\mathrm{Co} / \mathrm{Cr}$ molar ratios are close to those of the nominal values because the catalysts were prepared by a sol-gel method and no metal species were lost during the procedure.

The crystalline structures of the catalysts were determined by XRD, and the profiles are shown in Fig. 1. The $\mathrm{CoO}_{x}$ and $5 \mathrm{Co} 1 \mathrm{Cr}$ catalysts exhibit typical spinel structures of $\mathrm{Co}_{3} \mathrm{O}_{4}$ (JCPDS No. 42-1467), while the $2 \mathrm{Co} 1 \mathrm{Cr}$ catalyst shows a mixture of the spinel $\mathrm{Co}_{3} \mathrm{O}_{4}$ and $\mathrm{Co}_{2} \mathrm{CrO}_{4}$ (JCPDS No. 24-0326). Analyses of the lattice parameters further indicate the substitution of Co cations by $\mathrm{Cr}$ cations in the spinel $\mathrm{Co}_{3} \mathrm{O}_{4}$ matrix, as the lattice parameters increase from $0.8082 \mathrm{~nm}$ for $\mathrm{CoO}_{x}$ to $0.8101 \mathrm{~nm}$ for $2 \mathrm{Co} 1 \mathrm{Cr}$ because the ionic radius of the $\mathrm{Cr}^{3+}$ cation $(0.0615 \mathrm{~nm})$ is larger than that of the $\mathrm{Co}^{3+}$ cation $(0.0545$ $\mathrm{nm})$. For the $1 \mathrm{Co} 1 \mathrm{Cr}$ and $1 \mathrm{Co} 2 \mathrm{Cr}$ catalysts, only the standard spinel structure of $\mathrm{CoCr}_{2} \mathrm{O}_{4}$ (JCPDS No. 22-1084) is observed. It should be noted that the $\mathrm{Co} / \mathrm{Cr}$ molar ratio in the $1 \mathrm{Co} 1 \mathrm{Cr}$ sample is inconsistent with the stoichiometric formula of the spinel

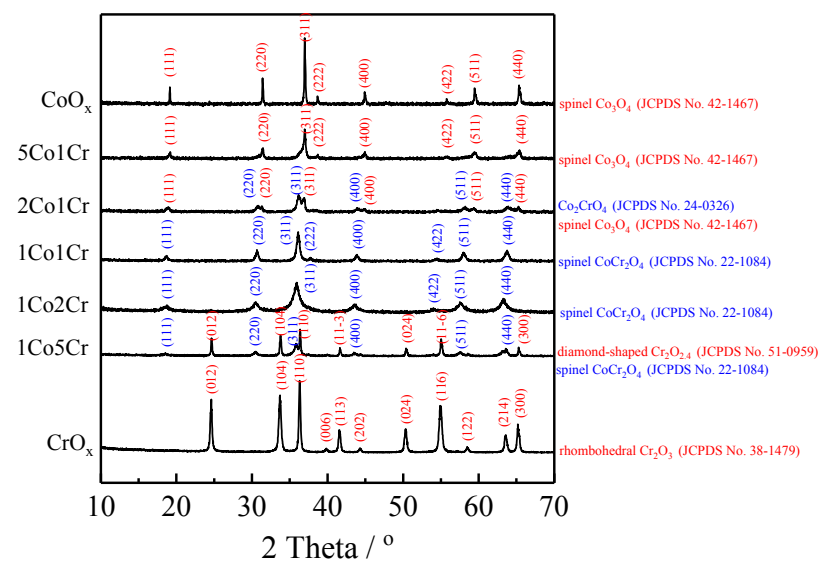

Fig. 1. XRD patterns of various $x \operatorname{CoyCr}$ catalysts. 
$\mathrm{CoCr}_{2} \mathrm{O}_{4}$. Moreover, compared to the case with $1 \mathrm{Co} 2 \mathrm{Cr}$, the diffractions of the $1 \mathrm{Co} 1 \mathrm{Cr}$ sample slightly shift toward relatively high angles, indicating the disordering of the spinel structure due to the nonstoichiometry of the $\mathrm{Co} / \mathrm{Cr}$ molar ratio in the 1Co1Cr mixed oxide [24]. In fact, the formula of a $\mathrm{CoCr}$ spinel oxide could be expressed as $\mathrm{Co}^{2+}\left[\mathrm{Co}^{3+}{ }_{2-x} \mathrm{Cr}^{3+}{ }_{x}\right] \mathrm{O}_{4}$, and in such a structure, $\mathrm{Co}^{3+}$ could partially occupy the octahedral sites when $\mathrm{Cr}^{3+}$ cations are insufficient. When the content of $\mathrm{Cr}^{3+}$ increases, the $\mathrm{Cr}^{3+}$ cations could re-occupy the octahedral sites and replace the $\mathrm{Co}^{3+}$ cations [30]. This explains the observed $\mathrm{CoCr}_{2} \mathrm{O}_{4}$ spinel structure in both $1 \mathrm{Co} 1 \mathrm{Cr}$ and $1 \mathrm{Co} 2 \mathrm{Cr}$ catalysts, which is further verified by the larger lattice parameter of $1 \mathrm{Co} 2 \mathrm{Cr}$ $(0.8327 \mathrm{~nm})$ than that of $1 \mathrm{Co} 1 \mathrm{Cr}(0.8273 \mathrm{~nm})$ because of the replacement of the $\mathrm{Co}^{3+}$ cations by the $\mathrm{Cr}^{3+}$ cations in the octahedral sites. However, the possible formation of the spinel $\mathrm{Co}_{3} \mathrm{O}_{4}$ oxide in $1 \mathrm{Co} 1 \mathrm{Cr}$ cannot be ruled out as the patterns are quite similar. The $1 \mathrm{Co5} \mathrm{Cr}$ sample consists of a mixture of a $\mathrm{CoCr}_{2} \mathrm{O}_{4}$ spinel oxide and a diamond-shaped $\mathrm{Cr}_{2} \mathrm{O}_{2.4}$ oxide ((JCPDS No. 51-0959). Once more, the lattice parameters of the $\mathrm{CoCr}_{2} \mathrm{O}_{4}$ spinel oxide in the $1 \mathrm{Co} 5 \mathrm{Cr}$ catalyst $(0.8331 \mathrm{~nm})$ are larger than those in $1 \mathrm{Co} 1 \mathrm{Cr}$ and $1 \mathrm{Co} 2 \mathrm{Cr}$, confirming the replacement of the $\mathrm{Co}^{3+}$ cations by $\mathrm{Cr}^{3+}$ cations [26]. However, the evolution of the $\mathrm{Cr}_{2} \mathrm{O}_{2.4}$ oxide suggests a phase segregation with excessive $\mathrm{Cr}$ species. The pure $\mathrm{CrO}_{x}$ shows different diffraction characteristics of the rhombohedral $\mathrm{Cr}_{2} \mathrm{O}_{3}$ oxide (JCPDS No. 38-1479). The crystallite sizes and lattice parameters of the catalyst were analyzed by the JADE software, and the results are summarized in Table 1 . It is found that $\mathrm{CoO}_{x}$ has the largest crystallite size ( $>100 \mathrm{~nm}$ ), and the addition of Cr results in a decline in the crystallite size, with the $1 \mathrm{Co} 2 \mathrm{Cr}$ having the smallest size $(8.0 \mathrm{~nm})$. The changes in the crystallite sizes of the mixed oxides explain the varying surface areas of the samples, and it appears that the Cr-Co interaction helps to inhibit the growth of crystallite, thus increasing the surface area.

The structural properties of the catalysts are further investigated by Raman spectroscopy (Fig. 2). $\mathrm{CoO}_{x}$ and $5 \mathrm{Co} 1 \mathrm{Cr}$ show

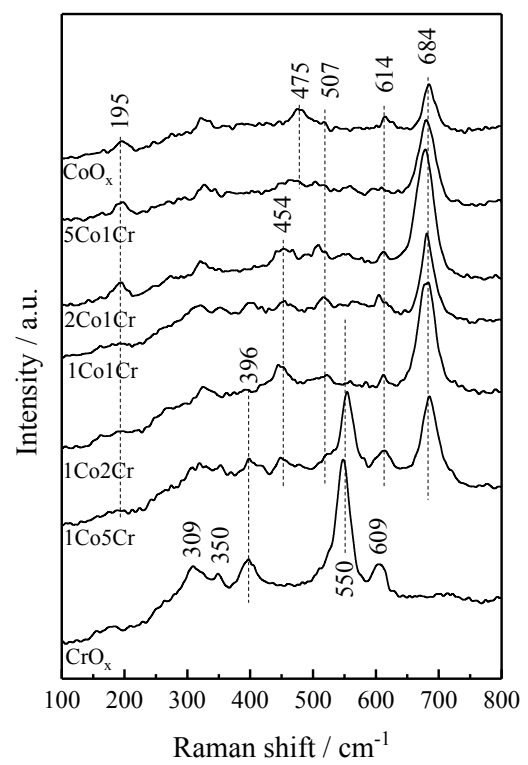

Fig. 2. Raman spectra of various $x \operatorname{CoyCr}$ catalysts. five bands at $195,475,507,614$, and $684 \mathrm{~cm}^{-1}$, which are characteristic of the spinel $\mathrm{Co}_{3} \mathrm{O}_{4}$ oxide corresponding to the $\mathrm{F}_{2 \mathrm{~g}}, \mathrm{E}_{\mathrm{g}}$, $\mathrm{F}_{2 \mathrm{~g}}, \mathrm{~F}_{2 \mathrm{~g}}$, and $\mathrm{A}_{1 \mathrm{~g}}$ vibration modes, respectively [31]. For $2 \mathrm{Co} 1 \mathrm{Cr}$, $1 \mathrm{Co} 1 \mathrm{Cr}$, and $1 \mathrm{Co} 2 \mathrm{Cr}$, there are also five bands at 195, 454, 507, 614 , and $684 \mathrm{~cm}^{-1}$, which could be respectively assigned to the $\mathrm{F}_{2 \mathrm{~g}}, \mathrm{Eg}_{\mathrm{g}}, \mathrm{F}_{2 \mathrm{~g}}, \mathrm{~F}_{2 \mathrm{~g}}$, and $\mathrm{A}_{1 \mathrm{~g}}$ vibration modes of the spinel $\mathrm{CoCr}_{2} \mathrm{O}_{4}$ oxide $[32,33]$. Note that $2 \mathrm{Co} 1 \mathrm{Cr}$ contains mixed phases of $\mathrm{Co}_{3} \mathrm{O}_{4}$ and $\mathrm{CoCr}_{2} \mathrm{O}_{4}$, although the Raman vibrations of these two oxides are similar due to their similar spinel structures. For the $1 \mathrm{Co} 5 \mathrm{Cr}$ catalyst, in addition to the bands indicative of the spinel $\mathrm{CoCr}_{2} \mathrm{O}_{4}$, new bands at 309, 350, 396, and $550 \mathrm{~cm}^{-1}$ are observed, which are assigned to the $\mathrm{CrO}_{x}$ oxide [34]. The phase transformation is completed on the $\mathrm{CrO}_{x}$ oxide, in which only the features of $\mathrm{CrO}_{x}$ are observed. The Raman spectroscopic results are in good agreement with the XRD results (Fig. 1), illustrating the structural change in the oxides depending on the Co/Cr molar ratios.

The catalyst reducibility was determined by the $\mathrm{H}_{2}-\mathrm{TPR}$ technique and the profiles are shown in Fig. 3. The $\mathrm{CrO}_{x}$ catalyst only shows a broad and weak reduction peak at $150-300{ }^{\circ} \mathrm{C}$ attributed to the reduction of $\mathrm{Cr}^{6+}$ to $\mathrm{Cr}^{3+}$ [35], and its total $\mathrm{H}_{2}$ consumption is $0.42 \mathrm{mmol} \mathrm{g}^{-1}$. The $1 \mathrm{Co} 5 \mathrm{Cr}, 1 \mathrm{Co} 2 \mathrm{Cr}$, and $1 \mathrm{Co} 1 \mathrm{Cr}$ catalysts show one reduction peak at $200-300{ }^{\circ} \mathrm{C}$ and a reduction peak at a high temperature $\left(>550{ }^{\circ} \mathrm{C}\right)$, which are attributed to the reduction of $\mathrm{Cr}^{6+}$ to $\mathrm{Cr}^{3+}$ [36] and the reduction of $\mathrm{Cr}^{3+}$ to lower oxidation states [24] in a $\mathrm{CoCr}_{2} \mathrm{O}_{4}$ spinel oxide, respectively. The total $\mathrm{H}_{2}$ consumptions of these catalysts are $0.48,1.17$, and $2.92 \mathrm{mmol} \mathrm{g}^{-1}$. For the Co-rich catalysts (those with a $\mathrm{Co} / \mathrm{Cr}$ ratio higher than 1 ), the reduction profiles change considerably. The $2 \mathrm{Co} 1 \mathrm{Cr}$ and $5 \mathrm{Co} 1 \mathrm{Cr}$ catalysts both show a weak reduction peak at a low temperature $\left(<300{ }^{\circ} \mathrm{C}\right)$ and an intensive and overlapped peak at $300-550{ }^{\circ} \mathrm{C}$. The peak centered at $380^{\circ} \mathrm{C}$ is due to the reduction of $\mathrm{Co}_{3} \mathrm{O}_{4}$ to $\mathrm{CoO}$ [38], and the peak centered at $500{ }^{\circ} \mathrm{C}$ is due to the reduction of $\mathrm{CoO}$ to metallic $\mathrm{Co}[14,37]$. The $\mathrm{H}_{2}$ consumptions of the two catalysts are 7.68 and $13.42 \mathrm{mmol} \mathrm{g}^{-1}$. The $\mathrm{CoO}_{x}$ catalyst showed an asymmetric reduction peak centered at $430{ }^{\circ} \mathrm{C}$, which could be attributed to the combined reduction of $\mathrm{Co}_{3} \mathrm{O}_{4}$ to $\mathrm{CoO}$ and sequentially to metallic Co [38,39], and its $\mathrm{H}_{2}$ consumption is $17.87 \mathrm{mmol} \mathrm{g}^{-1}$. Moreover, the reduction of the $\mathrm{Co}^{3+}$ species in

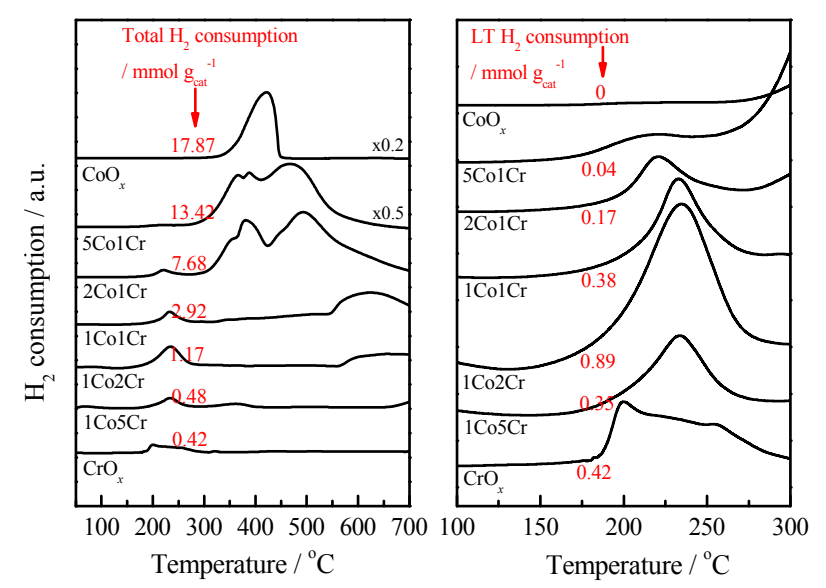

Fig. 3. $\mathrm{H}_{2}$-TPR profiles of various $x$ CoyCr catalysts. 


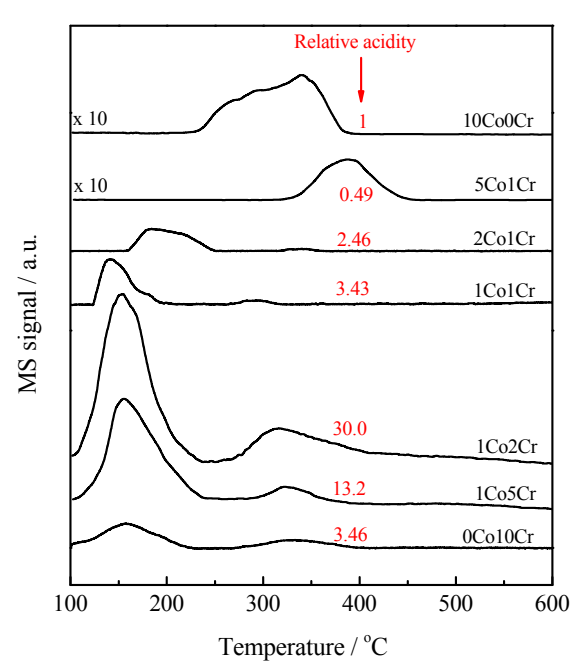

Fig. 4. $\mathrm{NH}_{3}$-TPD profiles of various $x \mathrm{CoyCr}$ catalysts.

the $2 \mathrm{Co} 1 \mathrm{Cr}$ and $5 \mathrm{Co} 1 \mathrm{Cr}$ catalysts to $\mathrm{Co}^{2+}$ is easier than that in the $\mathrm{CoO}_{x}$ catalyst, while that of $\mathrm{Co}^{2+}$ to metallic $\mathrm{Co}$ is more difficult. This is likely due to the strong interaction between cobalt oxide and chromium oxide [24]. The right panel of Fig. 3 presents the TPR profiles of the catalyst at a low-temperature (LT) range $\left(100-300{ }^{\circ} \mathrm{C}\right)$ because the LT reducibility reflects the mobility of the oxygen species in the catalyst, which is crucial in the oxidation reaction, particularly at low reaction temperatures [40]. Unlike the total $\mathrm{H}_{2}$ consumption, the $\mathrm{LT} \mathrm{H}_{2}$ consumption of the catalysts follow the order of $1 \mathrm{Co} 2 \mathrm{Cr}(0.89$ mmol g-1) $>\mathrm{CrO}_{x}\left(0.42 \mathrm{mmol} \mathrm{g}^{-1}\right)>1 \mathrm{Co} 1 \mathrm{Cr}\left(0.38 \mathrm{mmol} \mathrm{g}^{-1}\right)>$ $1 \mathrm{Co} 5 \mathrm{Cr}\left(0.35 \mathrm{mmol} \mathrm{g}^{-1}\right)>2 \mathrm{Co} 1 \mathrm{Cr}\left(0.17 \mathrm{mmol} \mathrm{g}^{-1}\right)>5 \mathrm{Co} 1 \mathrm{Cr}$ $\left(0.04 \mathrm{mmol} \mathrm{g}^{-1}\right)>\mathrm{CoO}_{x}\left(0 \mathrm{mmol} \mathrm{g}^{-1}\right)$.

Fig. 4 shows the $\mathrm{NH}_{3}-\mathrm{TPD}$ profiles of the catalysts. The $\mathrm{CrO}_{x}$, $1 \mathrm{Co} 5 \mathrm{Cr}, 1 \mathrm{Co} 2 \mathrm{Cr}, 1 \mathrm{Co} 1 \mathrm{Cr}$, and $2 \mathrm{Co} 1 \mathrm{Cr}$ catalysts show similar profiles, although their peak areas are very different. The five catalysts show $\mathrm{NH}_{3}$ desorption peaks at $100-230{ }^{\circ} \mathrm{C}$, indicating the presence of weak acid sites in these catalysts. In addition, relatively weak desorption peaks at $300-400{ }^{\circ} \mathrm{C}$ are observed, suggesting the presence of surface acid sites with medium strength. In contrast, the $5 \mathrm{Co} 1 \mathrm{Cr}$ and $\mathrm{CoO}_{x}$ catalysts give only very weak desorption peaks at $250-450{ }^{\circ} \mathrm{C}$, indicating the presence of medium acid sites and the absence of weak acid sites in these two catalysts. The total numbers of surface acid sites in the catalysts differ considerably. The $\mathrm{CoO}_{x}$ and $5 \mathrm{Co} 1 \mathrm{Cr}$ catalysts have a very low relative surface acidity (0.49-1); the $2 \mathrm{Co} 1 \mathrm{Cr}, 1 \mathrm{Co} 1 \mathrm{Cr}$, and oCo10Cr catalysts have medium surface acidities (2.46-3.46), while $1 \mathrm{Co} 2 \mathrm{Cr}$ and $1 \mathrm{Co} 5 \mathrm{Cr}$ have a high surface acidity (13.2-30.0). The significantly different values are related to the crystalline structure, crystallite size, and surface area of the catalysts. It was reported that $\mathrm{CrO}_{x}$ has a high surface acidity due to the presence of high-valent $\mathrm{Cr}^{6+}$ species, while $\mathrm{CoO}_{x}$ is less acidic [25]. Notably, the $1 \mathrm{Co} 2 \mathrm{Cr}$ mixed oxide has the highest surface acidity due to its spinel structure [24]. Moreover, it is found that the surface acidity of the catalysts generally follows the order of the surface area, which is understandable because the relatively small crystallite size of the oxide particles (high surface area) leads to an increased number of defects on the surface and more exposed cations, such as $\mathrm{Cr}^{6+}$ and $\mathrm{Co}^{3+}$. This explains the observed highest surface acidity on the $1 \mathrm{Co} 2 \mathrm{Cr}$ sample as it has the highest surface area (86 $\mathrm{m}^{2} \mathrm{~g}^{-1}$, Table 1).

The oxidation states of the $\mathrm{Co}, \mathrm{Cr}$, and $\mathrm{O}$ species in the catalysts were determined by XPS (Fig. 5). The Co $2 p_{3 / 2}$ spectra (Fig. 5(a)) could be resolved to three components at binding energies (BEs) of 780.3, 782.0, and $788.1 \mathrm{eV}$, assigned to $\mathrm{Co}^{2+}$, $\mathrm{Co}^{3+}$, and the satellite peak of $\mathrm{Co}^{2+}$, respectively [41]. These components gradually shift toward high BEs with increasing $\mathrm{Cr}$ content in the catalyst (up to $0.5 \mathrm{eV}$ ), suggesting the charge transfer from Co to $\mathrm{Cr}$ species. The $\mathrm{Cr} 2 p_{3 / 2}$ spectra (Fig. 5(b)) could be deconvoluted to three components at BEs of 575.3, 576.6, and $578.5 \mathrm{eV}$, which are assigned to $\mathrm{Cr}(\mathrm{OH})_{3}$ or $\mathrm{Cr}_{2} \mathrm{O}_{3}$, $\mathrm{Cr}^{3+}$ (occupied octahedral sites) and $\mathrm{Cr}^{6+}[25,26]$, respectively. The $\mathrm{Cr} 2 p 3 / 2$ peaks gradually shift toward low BEs with increasing contents of Co in the catalyst (up to $0.5 \mathrm{eV}$ ). This observation is in good agreement with Fig. 5(a), further suggesting that the $\mathrm{Co}-\mathrm{Cr}$ interaction results in the charge transfer between the Co and $\mathrm{Cr}$ species. For the $\mathrm{O} 1 \mathrm{~s}$ spectra, Fig. 5(c) shows that all the catalysts contain a major component at BEs in the range of 529.8-530.2 eV, assigned to the lattice oxygen (labeled as "Olatt"), and a minor component at a BE of $531.6 \mathrm{eV}$
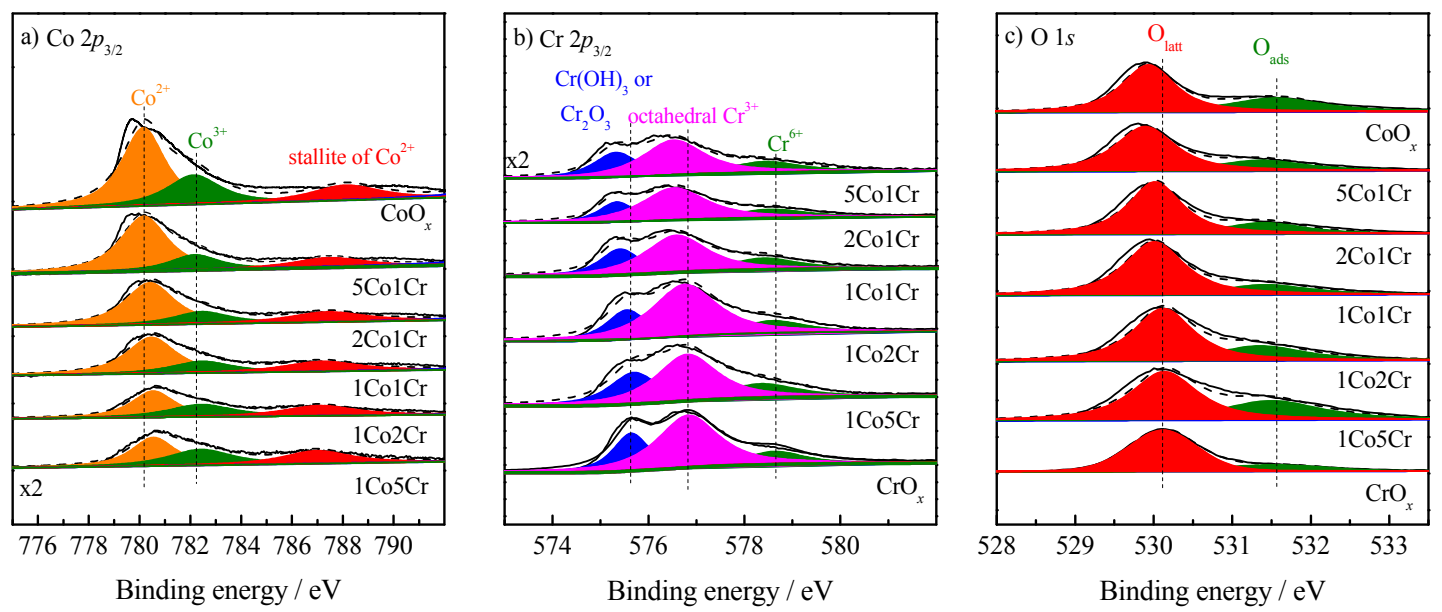

Fig. 5. XPS spectra of Co $2 p$ (a), Cr $2 p$ (b), and O $1 s$ (c) in various $x$ CoyCr catalysts. 
Table 2

XPS analysis of the $\mathrm{Cr}, \mathrm{Co}$, and $\mathrm{O}$ species in various $x \mathrm{CoyCr}$ catalysts.

\begin{tabular}{|c|c|c|c|c|c|c|c|c|c|}
\hline \multirow{2}{*}{ Catalyst } & \multicolumn{6}{|c|}{ Surface concentration / \% } & \multicolumn{3}{|c|}{ Surface molar ratio } \\
\hline & $\mathrm{Co}^{2+}$ & $\mathrm{Co}^{3+}$ & $\mathrm{Cr}^{3+}$ & $\mathrm{Cr}^{6+}$ & $\mathrm{O}_{\text {latt }}$ & $\mathrm{O}_{\text {ads }}$ & $\mathrm{Co}^{3+} / \mathrm{Co}^{2+}$ & $\mathrm{Cr}^{6+} / \mathrm{Cr}^{3+}$ & $\mathrm{O}_{\text {ads }} / \mathrm{O}_{\text {latt }}$ \\
\hline$\overline{\mathrm{CoO}_{x}}$ & 68.1 & 31.9 & - & - & 65.9 & 34.1 & 0.47 & - & 0.52 \\
\hline $5 \mathrm{Co} 1 \mathrm{Cr}$ & 77.6 & 22.4 & 81.6 & 18.4 & 74.1 & 25.9 & 0.29 & 0.23 & 0.35 \\
\hline $2 \mathrm{Co} 1 \mathrm{Cr}$ & 75.3 & 24.7 & 82.5 & 17.6 & 75.6 & 24.4 & 0.33 & 0.21 & 0.32 \\
\hline $1 \mathrm{Co} 1 \mathrm{Cr}$ & 71.5 & 28.5 & 83.8 & 16.2 & 70.0 & 30.0 & 0.40 & 0.19 & 0.43 \\
\hline $1 \mathrm{Co} 2 \mathrm{Cr}$ & 58.6 & 41.4 & 85.3 & 14.7 & 77.8 & 22.2 & 0.70 & 0.17 & 0.29 \\
\hline $1 \mathrm{Co} 5 \mathrm{Cr}$ & 54.8 & 45.2 & 85.9 & 14.1 & 62.7 & 37.3 & 0.83 & 0.16 & 0.59 \\
\hline $\mathrm{CrO}_{x}$ & - & - & 85.6 & 14.4 & 80.3 & 19.7 & - & 0.17 & 0.25 \\
\hline
\end{tabular}
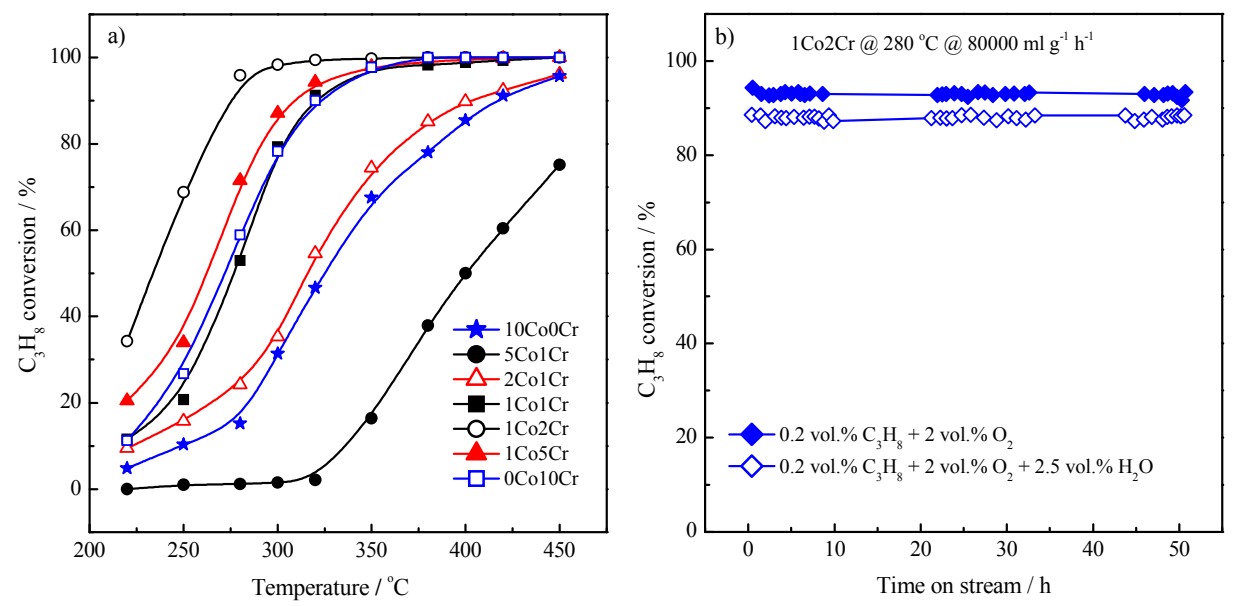

Fig. 6. (a) Propane conversions of various $x \operatorname{Coy} \mathrm{Cr}$ catalysts at different temperatures; (b) catalyst stability of $1 \mathrm{Co} 2 \mathrm{Cr}$ under dry and wet reaction conditions.

indicative of the surface oxygen or hydroxyl group (labeled as " $\mathrm{O}_{\text {ads }}$ ") [42]. Note that the position of the $\mathrm{O}_{\text {latt }}$ component in the catalysts also shifts toward lower BEs with increasing Co content, which reflects the different properties of the mixed oxides. The surface concentrations of various species are summarized in Table 2. The results show that the co-presence of $\mathrm{Co}$ and $\mathrm{Cr}$ in the mixed oxides results in changes in the surface contents of the $\mathrm{Co}$ and $\mathrm{Cr}$ species. The $\mathrm{Co}^{3+} / \mathrm{Co}^{2+}$ ratio generally increases with increasing $\mathrm{Cr}$ content in the catalyst (from 0.29 for the $5 \mathrm{Co} 1 \mathrm{Cr}$ to 0.83 for the $1 \mathrm{Co} 5 \mathrm{Cr}$ ), while the $\mathrm{Cr}^{6+} / \mathrm{Cr}^{3+}$ ratio gradually declines (from 0.23 for $5 \mathrm{Co} 1 \mathrm{Cr}$ to 0.16 for $1 \mathrm{Co} 5 \mathrm{Cr}$ ), which further suggests the $\mathrm{Co}-\mathrm{Cr}$ interaction and charge transfer between these two species.

\subsection{Catalytic activities of the catalysts}

The catalytic behaviors of the catalysts at elevated reaction temperatures are shown in Fig. 6(a). The activities follow the order of $1 \mathrm{Co} 2 \mathrm{Cr}>1 \mathrm{Co} 5 \mathrm{Cr}>\mathrm{CrO}_{x}>1 \mathrm{Co} 1 \mathrm{Cr}>2 \mathrm{Co} 1 \mathrm{Cr}>\mathrm{CoO}_{x}>$ $5 \mathrm{Co} 1 \mathrm{Cr}$. Table 3 summarizes the detailed results of the catalysts, which shows that the $1 \mathrm{Co} 2 \mathrm{Cr}$ catalyst affords the highest propane conversion at $250{ }^{\circ} \mathrm{C}(68.8 \%)$, with the highest mass-specific reaction rate of $1.38 \times 10^{-6} \mathrm{~mol} \mathrm{~g}^{-1} \mathrm{~s}^{-1}$. However, if the mass reaction rates are normalized based on the surface areas of the catalysts, it is found that the catalysts give similar areal reaction rates of approximately $1.6-2.1 \times 10^{-8} \mathrm{~mol} \mathrm{~m}^{-2} \mathrm{~s}^{-1}$ with the exception of those on $\mathrm{CoO}_{x}\left(10.3 \times 10^{-8} \mathrm{~mol} \mathrm{~m}^{-2} \mathrm{~s}^{-1}\right)$ and $5 \mathrm{Co} 1 \mathrm{Cr}\left(0.2 \times 10^{-8} \mathrm{~mol} \mathrm{~m}^{-2} \mathrm{~s}^{-1}\right)$. The large deviations on the latter two catalysts might be due to the large errors in the measurements of the surface areas of these two catalysts as the values are very low. Fig. 6(b) shows the stability of the representative $1 \mathrm{Co} 2 \mathrm{Cr}$ catalyst under dry $\left(\mathrm{C}_{3} \mathrm{H}_{8}+\mathrm{O}_{2}\right)$ and wet $\left(\mathrm{C}_{3} \mathrm{H}_{8}\right.$ $+\mathrm{O}_{2}+\mathrm{H}_{2} \mathrm{O}$ ) conditions at $280{ }^{\circ} \mathrm{C}$. The catalyst exhibits good stability in a 50-h reaction, under either dry or wet condition, although the activity is slightly suppressed (with the propane conversion declining by ca. $6 \%$ ) in the presence of $2.5 \mathrm{vol} \%$ in the feedstock. The inhibiting role of water vapor is usually due to the competitive adsorption of water and the reactants on the catalytic sites, which has been reported in the total oxidation of methane over $\mathrm{CoO}_{x}-\mathrm{CrO}_{x}$ mixed oxides [24] and $\mathrm{Co}_{3} \mathrm{O}_{4} / \mathrm{CeO}_{2}$ catalysts [43].

The findings in the current work indicate that the $\mathrm{Co}-\mathrm{Cr}$

Table 3

Summary of the catalytic performance of the catalysts at $250^{\circ} \mathrm{C}$.

\begin{tabular}{|c|c|c|c|}
\hline \multirow{2}{*}{ Catalyst } & \multirow{2}{*}{$\begin{array}{c}\text { Propane } \\
\text { conversion/ \% }\end{array}$} & \multicolumn{2}{|c|}{ Specific reaction rate } \\
\hline & & $/ \times 10^{-6} \mathrm{~mol} \mathrm{~g}^{-1} \mathrm{~s}^{-1}$ & $/ \times 10^{-8} \mathrm{~mol} \mathrm{~m}^{-2} \mathrm{~s}^{-1}$ \\
\hline$\overline{\mathrm{CoO}_{x}}$ & 10.3 & 0.21 & 10.3 \\
\hline $5 \mathrm{Co} 1 \mathrm{Cr}$ & 1.0 & 0.01 & 0.2 \\
\hline $2 \mathrm{Co} 1 \mathrm{Cr}$ & 15.7 & 0.32 & 2.1 \\
\hline $1 \mathrm{Co} 1 \mathrm{Cr}$ & 20.7 & 0.42 & 2.1 \\
\hline $1 \mathrm{Co} 2 \mathrm{Cr}$ & 68.8 & 1.38 & 1.6 \\
\hline $1 \mathrm{Co} 5 \mathrm{Cr}$ & 33.9 & 0.68 & 1.8 \\
\hline $\mathrm{CrO}_{x}$ & 26.7 & 0.54 & 2.0 \\
\hline
\end{tabular}


mixed oxides are effective for the total oxidation of propane. The highest reaction rate is obtained on $1 \mathrm{Co} 2 \mathrm{Cr}\left(1.38 \times 10^{-6}\right.$ mol g-1 $\mathrm{s}^{-1}$ at $250^{\circ} \mathrm{C}$ ), which is comparable to those reported in the literature. For example, at $250{ }^{\circ} \mathrm{C}$, it was reported that a $\mathrm{NiCeO}_{x}$ catalyst gave a reaction rate of $0.11 \times 10^{-6} \mathrm{~mol} \mathrm{~g}^{-1} \mathrm{~s}^{-1}$ [17]; $\mathrm{F} \mathrm{FeO}_{x}$ catalyst gave a reaction rate of $0.05 \times 10^{-6} \mathrm{~mol} \mathrm{~g}^{-1}$ $\mathrm{s}^{-1}$ [20]; a $\mathrm{CoO}_{x}$ catalyst gave a reaction rate of $1.23 \times 10^{-6} \mathrm{~mol}$ $\mathrm{g}^{-1} \mathrm{~s}^{-1}$ [21]; a $\mathrm{Ni}_{0.27} \mathrm{Co}_{2.73} \mathrm{O}_{4}$ catalyst gave a reaction rate of 5.58 $\times 10^{-6} \mathrm{~mol} \mathrm{~g}^{-1} \mathrm{~s}^{-1}$ [16]; and a Co1Ce1 catalyst gave a reaction rate of $4.46 \times 10^{-6} \mathrm{~mol} \mathrm{~g}^{-1} \mathrm{~s}^{-1}$ [42]. More detailed comparisons are summarized in Table S1.

It is well documented in literature that for propane combustion, the surface acidity and reducibility of the catalyst are two crucial parameters governing the catalytic performance. The acidic sites in the catalyst are believed to provide adsorption centers for the propane molecules [27] and/or activate the propane molecule by cleaving the $\mathrm{C}-\mathrm{H}$ bond [44], which has been verified over the Pt catalysts supported on acidic zeolites, such as KL, HY, ZSM-5, and beta zeolites [29]. Garetto et al. [29] found that the supported Pt/Zeolites catalysts were more active than the $\mathrm{Pt} / \mathrm{Al}_{2} \mathrm{O}_{3}$ catalysts, owing to the comparatively high propane uptake related to the high surface acidity of the zeolite supports. Conversely, the reducibility of the catalyst is related to the adsorption and/or activation of oxygen species, which is an essential process during the oxidation reaction [14]. Based on the $\mathrm{NH}_{3}-\mathrm{TPD}$ (Fig. 4) and $\mathrm{H}_{2}$-TPR (Fig. 3) results, in the current work, the influences of these two parameters on the catalytic behaviors of various catalysts are demonstrated in Fig. 7. Evidently, the reaction rate increases with as both the surface acidity and LT- $\mathrm{H}_{2}$ consumption increase, suggesting the synergistic effects of the two parameters on the catalytic performance. Therefore, the best activity on $1 \mathrm{Co} 2 \mathrm{Cr}$ is owing to its highest surface acidity and highest LT- $\mathrm{H}_{2}$ consumption. It is worthwhile to discuss the structure of the $1 \mathrm{Co} 2 \mathrm{Cr}$ catalyst, which is a spinel-type cobalt chromite oxide $\left(\mathrm{CoCr}_{2} \mathrm{O}_{4}\right)$, as shown in Fig. 1. In the $\mathrm{CoCr}_{2} \mathrm{O}_{4}$ structure, Co and $\mathrm{Cr}$ cations are confined in a solid matrix, in which the high-spin divalent $\mathrm{Co}^{2+}$ cations mostly occupy the tetrahedral sites, while

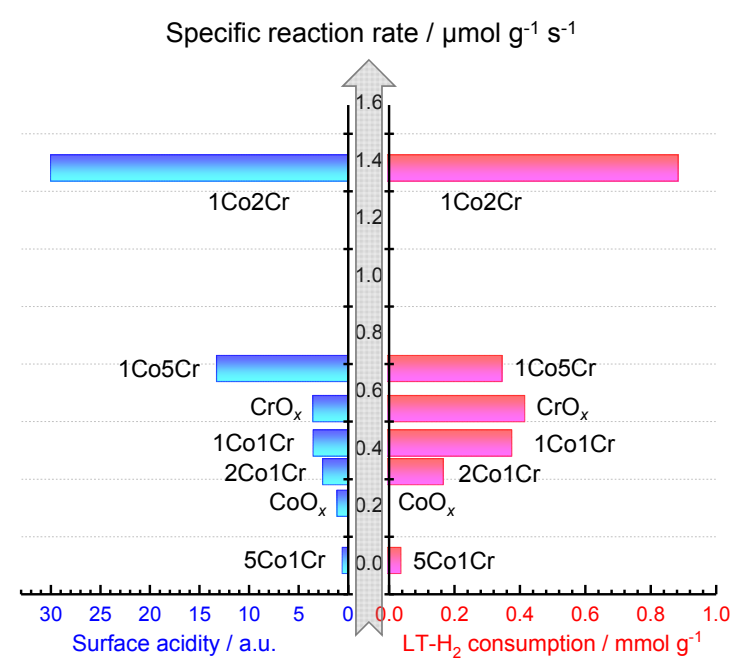

Fig. 7. Influences of the surface acidity and LT-reducibility on the reaction rates of the catalysts. the low-spin trivalent $\mathrm{Cr}^{3+}$ cations occupy the octahedral sites [45]. For the spinel-type oxides $\left(\mathrm{AB}_{2} \mathrm{O}_{4}\right)$ in catalytic reactions, the octahedral $\mathrm{B}$-site cations are the active sites because these cations are exposed at the surface, while the tetrahedral A-site cations are usually inactive [25]. The $\mathrm{CoCr}_{2} \mathrm{O}_{4}$ spinel oxide has been widely applied in the catalytic combustion of VOCs (including chlorinated-VOCs, CVOCs), and its excellent performance is attributed to the presence of $\mathrm{B}$-site $\mathrm{Cr}$ species $\left(\mathrm{Cr}^{3+}\right.$ or $\mathrm{Cr}^{6+}$ ) in the oxide [25,46,47]. Chen et al. [24] prepared a series of $\mathrm{Co}-\mathrm{Cr}-\mathrm{O}$ mixed oxides for methane combustion, and they found that the catalyst with a Co/Cr molar ratio of $1: 2$ showed the best performance due to its spinel structure and the presence of high-valent $\mathrm{Cr}^{6+}$ species, which enhanced the adsorption of chemisorbed oxygen species. Another important issue that should be addressed is the catalyst surface area. Although the mixed oxides were prepared under identical conditions, the surface areas change from very low $\left(2 \mathrm{~m}^{2} \mathrm{~g}^{-1}\right.$ for the $\left.\mathrm{CoO}_{x}\right)$ to high $\left(86 \mathrm{~m}^{2} \mathrm{~g}^{-1}\right.$ for the $\left.1 \mathrm{Co} 2 \mathrm{Cr}\right)$, which strongly depends on the element compositions. The $2 \mathrm{Co} 1 \mathrm{Cr}, 1 \mathrm{Co} 1 \mathrm{Cr}, 1 \mathrm{Co} 2 \mathrm{Cr}$, and $1 \mathrm{Co} 5 \mathrm{Cr}$ catalysts all contain the spinel $\mathrm{CoCr}_{2} \mathrm{O}_{4}$ oxide, although their surface areas vary from 15 to $86 \mathrm{~m}^{2} \mathrm{~g}^{-1}$. Generally, oxides with relatively small crystallite sizes (high surface areas) contain more defect sites than the bulk oxides. This leads to easy adsorption of oxygen species and thus high reducibility. The different surface areas of the above-mentioned catalysts account for the observed overall mass reaction rates, as they give similar areal reaction rates (c. a. $2.0 \times 10^{-8} \mathrm{~mol} \mathrm{~m}^{-2} \mathrm{~s}^{-1}$ ). Moreover, it was reported that $\mathrm{Co}_{3} \mathrm{O}_{4}$ oxides are effective for propane combustion $[15,18]$; however, $\mathrm{CoO}_{x}$ and $5 \mathrm{Co} 1 \mathrm{Cr}$ are less active in the current work, probably due to their very low surface areas and consequently low surface acidity (Fig. 4) and poor redox properties (Fig. 3).

\section{3. $\mathrm{C}_{3} \mathrm{H}_{8}-$ TPSR and kinetic investigation}

To further investigate the different behaviors of the catalysts, $\mathrm{C}_{3} \mathrm{H}_{8}$-TPSR experiments were conducted on the three samples $(1 \mathrm{Co} 5 \mathrm{Cr}, 1 \mathrm{Co} 2 \mathrm{Cr}$, and $2 \mathrm{Co} 1 \mathrm{Cr}$ ) representing high, medium, and low reaction rates. As shown in Fig. 8(a), the $1 \mathrm{Co} 5 \mathrm{Cr}$ catalyst shows consumption of $\mathrm{C}_{3} \mathrm{H}_{8}$ (a negative peak) at 480 ${ }^{\circ} \mathrm{C}$, accompanied by a simultaneous appearance of a characteristic $\mathrm{CO}_{2}$ signal. For the $1 \mathrm{Co} 2 \mathrm{Cr}$ catalyst (Fig. 8(b)), distinct consumption of $\mathrm{C}_{3} \mathrm{H}_{8}$ is observed at about $190{ }^{\circ} \mathrm{C}$, along with the formation of $\mathrm{H}_{2} \mathrm{O}$ and $\mathrm{CO}_{2}$. In addition, much less intense consumption of $\mathrm{C}_{3} \mathrm{H}_{8}$ is detected at $536{ }^{\circ} \mathrm{C}$. For the $2 \mathrm{Co} 1 \mathrm{Cr}$ catalyst, Fig. 8(c) shows the $\mathrm{C}_{3} \mathrm{H}_{8}$ consumption and $\mathrm{CO}_{2}$ formation at $510{ }^{\circ} \mathrm{C}$. These profiles reflect different behaviors of the catalysts. Since there is no $\mathrm{O}_{2}$ feed during the process, the formation of $\mathrm{CO}_{2}$ on the catalyst is likely due to the reaction between propane and the surface oxygen (or lattice oxygen) species. Moreover, the finding on $1 \mathrm{Co} 2 \mathrm{Cr}$ suggests that there are two different oxygen species involved in the reaction, and the formation of $\mathrm{CO}_{2}$ at ca. $200{ }^{\circ} \mathrm{C}$ might explain the relatively high activity on this catalyst, particularly at a low-temperature region. However, the nature of the oxygen species cannot be explicated at present and will be further discussed based on the kinetic results. 


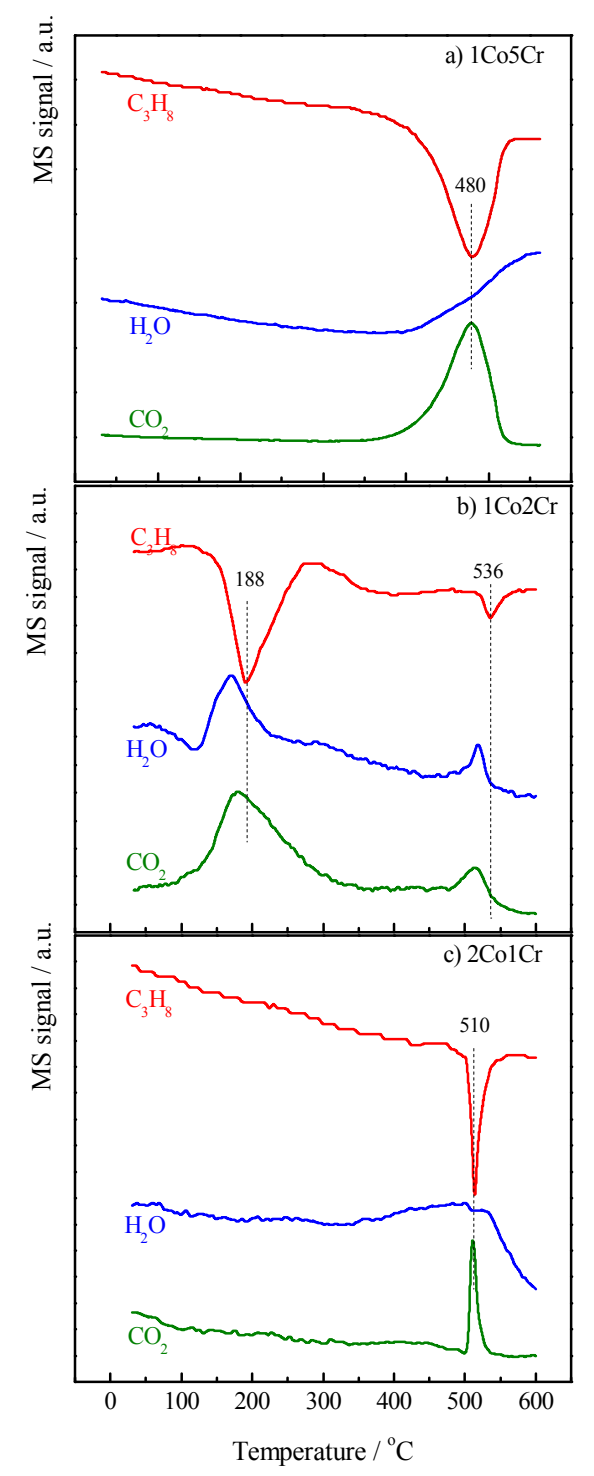

Fig. 8. $\mathrm{C}_{3} \mathrm{H}_{8}-\mathrm{TPSR}$ profiles of the $1 \mathrm{Co} 5 \mathrm{Cr}(\mathrm{a}), 1 \mathrm{Co} 2 \mathrm{Cr}(\mathrm{b})$, and $2 \mathrm{Co} 1 \mathrm{Cr}(\mathrm{c})$ catalysts.

A kinetic study was also conducted on the $1 \mathrm{Co} 5 \mathrm{Cr}, 1 \mathrm{Co} 2 \mathrm{Cr}$, and $2 \mathrm{Co} 1 \mathrm{Cr}$ catalysts to gain some mechanistic insights. Under differential reaction mode (detailed results are summarized in Table S2), Fig. 9 shows that the reaction rate increases with increasing partial pressures of both $\mathrm{C}_{3} \mathrm{H}_{8}$ (Fig. 9(a)) and $\mathrm{O}_{2}$ (Fig. 9(b)). By linear regression of the data in Table $\mathrm{S} 2$, the reaction orders of $\mathrm{C}_{3} \mathrm{H}_{8}$ and $\mathrm{O}_{2}$, as well as the apparent rate constant could be deduced, which are summarized in Table 4. Thus, the power-law rate expressions for the catalysts are $r=7.32 \times 10^{-8}$ $\left[\mathrm{C}_{3} \mathrm{H}_{8}\right]^{0.77}\left[\mathrm{O}_{2}\right]^{0.98}$ for $2 \mathrm{Co} 1 \mathrm{Cr} ; r=42.60 \times 10^{-8}\left[\mathrm{C}_{3} \mathrm{H}_{8}\right]^{0.58}\left[\mathrm{O}_{2}\right]^{0.34}$ for $1 \mathrm{Co} 2 \mathrm{Cr} ; r=9.49 \times 10^{-8}\left[\mathrm{C}_{3} \mathrm{H}_{8}\right]^{0.66}\left[\mathrm{O}_{2}\right]^{1.30}$ for $1 \mathrm{Co} 5 \mathrm{Cr}$. Firstly, the apparent rate constant follows the order of $1 \mathrm{Co} 2 \mathrm{Cr}(42.60 \times$ $\left.10^{-8}\right)>>1 \operatorname{Co} 5 \mathrm{Cr}\left(9.49 \times 10^{-8}\right)>2 \operatorname{Co} 1 \mathrm{Cr}\left(7.32 \times 10^{-8}\right)$, suggesting the highest intrinsic activity of the $1 \mathrm{Co} 2 \mathrm{Cr}$ catalyst. This trend fits well with that of the overall activities (Table 3). Secondly, the reaction order of $\mathrm{C}_{3} \mathrm{H}_{8}$ follows the order of $1 \mathrm{Co} 2 \mathrm{Cr}$ $(0.58 \pm 0.03)<1 \mathrm{Co} 5 \mathrm{Cr}(0.66 \pm 0.05)<2 \mathrm{Co} 1 \mathrm{Cr}(0.77 \pm 0.02)$, indicating that the $\mathrm{C}_{3} \mathrm{H}_{8}$ surface coverages on these catalysts follow an opposite trend (highest propane coverage on $1 \mathrm{Co} 2 \mathrm{Cr}$ and lowest coverage on $2 \mathrm{Co} 1 \mathrm{Cr}$ ). This finding is probably related to the different surface acidity of the catalysts, as the surface acid sites are the adsorption centers for the $\mathrm{C}_{3} \mathrm{H}_{8}$ molecules [44]. The $\mathrm{NH}_{3}-\mathrm{TPD}$ results (Fig. 4) clearly show that $1 \mathrm{Co} 2 \mathrm{Cr}$ has the highest surface acidity; therefore, it provides the most abundant sites for $\mathrm{C}_{3} \mathrm{H}_{8}$ adsorption. Thirdly, the reaction order of $\mathrm{O}_{2}$ follows the order of $1 \mathrm{Co} 2 \mathrm{Cr}(0.34 \pm 0.05)<<2 \mathrm{Co} 1 \mathrm{Cr}(0.98$ $\pm 0.16)<1 \mathrm{Co} 5 \mathrm{Cr}(1.30 \pm 0.11)$, implying that the adsorption of the oxygen molecules on $1 \mathrm{Co} 2 \mathrm{Cr}$ is quite strong, while those on $2 \mathrm{Co} 1 \mathrm{Cr}$ and $1 \mathrm{Co} 5 \mathrm{Cr}$ are rather weak. It should be noted that the XPS results (Fig. 5(c)) reveal the presence of surface oxygen species on all the catalysts, which seems inconsistent with the hard adsorption of $\mathrm{O}_{2}$ on the $2 \mathrm{Co} 1 \mathrm{Cr}$ and $1 \mathrm{Co} 5 \mathrm{Cr}$ catalysts. The discrepancy may lie in the different reaction conditions of the measurements. Note that the kinetic study was conducted at a relatively high temperature $\left(245^{\circ} \mathrm{C}\right.$, Table S2), which is favorable for the desorption of oxygen. Moreover, the different reaction orders of $\mathrm{O}_{2}$ on the catalysts could explain the findings of the $\mathrm{C}_{3} \mathrm{H}_{8}$-TPSR results (Fig. 8). Since the formation of $\mathrm{CO}_{2}$ is observed at a very high temperature (ca. $500{ }^{\circ} \mathrm{C}$ ) on the $1 \mathrm{Co} 5 \mathrm{Cr}$ and $2 \mathrm{Co} 1 \mathrm{Cr}$ catalysts (Figs. 8(a) and (c)) and oxygen molecules hardly adsorb on these two catalysts (reaction order of 1 , Table 4), it could be deduced that the oxygen species on the catalysts are likely lattice oxygen instead of the adsorbed surface oxygen species. In contrast, the $1 \mathrm{Co} 2 \mathrm{Cr}$ catalyst induces $\mathrm{CO}_{2}$ formation at relatively low temperatures (ca. $200{ }^{\circ} \mathrm{C}$, Fig. 8(b)) and $\mathrm{O}_{2}$ molecules could readily adsorb on its surface; this low-temperature $\mathrm{CO}_{2}$ formation could be due to the reaction between $\mathrm{C}_{3} \mathrm{H}_{8}$ and adsorbed oxygen species rather than the lattice oxygen. The obtained reaction orders of $\mathrm{C}_{3} \mathrm{H}_{8}(0.58 \pm$ $0.03)$ and $\mathrm{O}_{2}(0.34 \pm 0.05)$ on the $1 \mathrm{Co} 2 \mathrm{Cr}$ catalyst are similar to those reported on the $\mathrm{NiCeO}_{\mathrm{x}}$ mixed oxides, in which the reaction orders of $\mathrm{C}_{3} \mathrm{H}_{8}$ were $0.42-0.57$ and those of $\mathrm{O}_{2}$ were 0.57-0.58 [17]. Additionally, Heynderickx et al. [48] reported $\mathrm{C}_{3} \mathrm{H}_{8}$ reaction orders of $0.21-0.27$ and $\mathrm{O}_{2}$ reaction orders of $0.22-0.25$ over a $\mathrm{CuO}-\mathrm{CeO}_{2} / \gamma-\mathrm{Al}_{2} \mathrm{O}_{3}$ catalyst. Furthermore, the parity plots and residual analyses (Fig. S1) show that the experimental values are well consistent with the theoretical values, thereby verifying the validity of the derived kinetic parameters. The calculated apparent activation energies for the $2 \mathrm{Co} 1 \mathrm{Cr}, 1 \mathrm{Co} 2 \mathrm{Cr}$, and $1 \mathrm{Co} 5 \mathrm{Cr}$ catalysts are $161.3 \pm 12.5,128.5 \pm$ 11.6 , and $161.3 \pm 12.7 \mathrm{~kJ} \mathrm{~mol}^{-1}$, respectively. These values are comparable to those reported for the $\mathrm{NiCeO}_{x}$ catalysts (99.1-113.4 kJ mol-1) [17], although they are higher than those reported for the Ni-doped $\mathrm{Co}_{3} \mathrm{O}_{4}\left(32.5-83.8 \mathrm{~kJ} \mathrm{~mol}^{-1}\right)$ [16], Niand Co-doped ferrite catalysts (15.8-39.6 kJ mol-1) [49], and $\mathrm{Co}_{3} \mathrm{O}_{4} / \mathrm{ZSM}-5$ catalysts $\left(62.8-104.0 \mathrm{~kJ} \mathrm{~mol}^{-1}\right)$ [14].

The mechanisms of propane combustion over transition metal oxides have been investigated in the literature. For example, very detailed kinetic modeling has been performed on $\mathrm{VO}_{x}-\mathrm{TiO}_{2} / \mathrm{SiO}_{2}$ [50] and $\mathrm{CuO}-\mathrm{CeO}_{2} / \gamma-\mathrm{Al}_{2} \mathrm{O}_{3}$ catalysts $[48,51]$. Thybaut and co-workers concluded that on the $\mathrm{VO}_{x}-\mathrm{TiO}_{2} / \mathrm{SiO}_{2}$ catalysts, the propane combustion follows a Mars-van Krevelen (MvK) mechanism involving one active site in the reduction and reoxidation step [50], while on the $\mathrm{CuO}-\mathrm{CeO}_{2} / \gamma-\mathrm{Al}_{2} \mathrm{O}_{3}$ cat- 

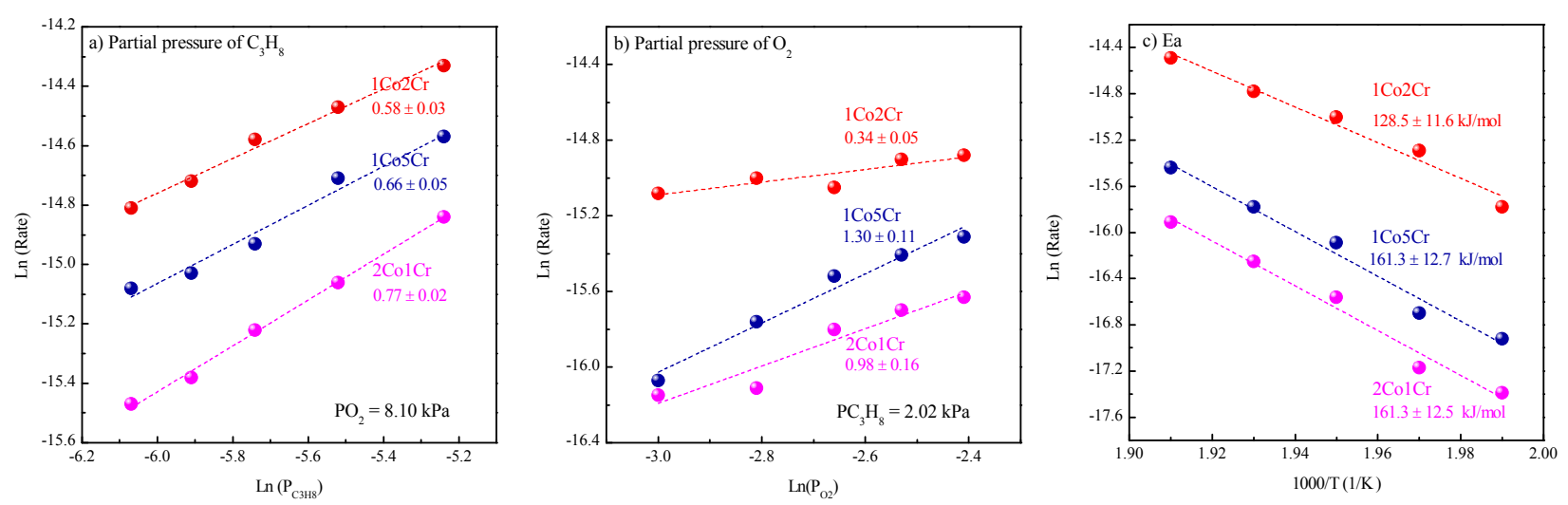

Fig. 9. Dependence of the reaction rates on the partial pressures of propane (a) and oxygen (b); (c) Arrhenius plots of the $2 \mathrm{Co} 1 \mathrm{Cr}$, 1 Co2Cr, and 1 Co5Cr catalysts.

alyst, the reaction follows a Langmuir-Hinshelwood (LH) mechanism involving the surface reaction between the adsorbed propane and dissociatively adsorbed oxygen species as the rate-determining step (RDS) [48]. Although the MvK mechanism (redox mechanism) is generally employed to explain the catalytic behaviors of various transition metal oxides $[16,50]$, such mechanism appear to not be applicable in the current work. One evidence is that the $\mathrm{C}_{3} \mathrm{H}_{8}$-TPSR results (Fig. 8) over the employed catalysts clearly show the formation of $\mathrm{CO}_{2}$ only at very high temperatures $\left(\mathrm{ca} .500^{\circ} \mathrm{C}\right.$ ) due to the reaction of $\mathrm{C}_{3} \mathrm{H}_{8}$ and lattice oxygen on the catalysts, which cannot explain the observed low temperature activities of the catalysts (Fig. 6) if the lattice oxygen is the active species in the reaction. Besides, if the reaction follows the MvK mechanism, one distinct feature in the kinetics is that the reaction order of $\mathrm{O}_{2}$ would be near zero because the gaseous $\mathrm{O}_{2}$ is not directly involved in the reaction (the role of gaseous $\mathrm{O}_{2}$ is to fill the surface oxygen vacancy on the catalyst surface). However, our kinetic results reveal that the reaction orders of $\mathrm{O}_{2}$ on the three catalysts are higher than zero (in the cases of $2 \mathrm{Co} 1 \mathrm{Cr}$ and $1 \mathrm{Co} 5 \mathrm{Cr}$, the orders are close to 1 ), which unambiguously indicate that the reaction pathways are different from the MvK mechanism. In the current work, the three catalysts employed in the kinetic studies all have a $\mathrm{C}_{3} \mathrm{H}_{8}$ reaction order of 0.58-0.66, indicating the adsorption of propane molecules on the catalyst surface. However, the reaction order of $\mathrm{O}_{2}$ for $1 \mathrm{Co} 2 \mathrm{Cr}$ is 0.34 , while those for $2 \mathrm{Co} 1 \mathrm{Cr}$ and $1 \mathrm{Co} 5 \mathrm{Cr}$ are close to 1 , which suggests that oxygen molecules could adsorb on $1 \mathrm{Co} 2 \mathrm{Cr}$ but hardly on $2 \mathrm{Co} 1 \mathrm{Cr}$ and $1 \mathrm{Co} 5 \mathrm{Cr}$. Considering that the apparent activation energies of the three catalysts are similar (128.5-161.3 kJ mol-1), it is likely that the reaction routes on

Table 4

Kinetic parameters on the $2 \mathrm{Co} 1 \mathrm{Cr}, 1 \mathrm{Co} 2 \mathrm{Cr}$, and $1 \mathrm{Co} 5 \mathrm{Cr}$ catalysts.

\begin{tabular}{lcccc}
\hline $\mathrm{r}=k_{\text {app }}\left[\mathrm{C}_{3} \mathrm{H}_{8}\right]^{a}\left[\mathrm{O}_{2}\right]^{b}$ & & & \\
\hline Catalyst & $k_{\text {app }} / \times 10^{-8}$ & $A$ & $b$ & $E a / \mathrm{kJ} \mathrm{mol}^{-1}$ \\
$2 \mathrm{Co} 1 \mathrm{Cr}$ & 7.32 & $0.77 \pm 0.02$ & $0.98 \pm 0.16$ & $161.3 \pm 12.5$ \\
$1 \mathrm{Co} 2 \mathrm{Cr}$ & 42.60 & $0.58 \pm 0.03$ & $0.34 \pm 0.05$ & $128.5 \pm 11.6$ \\
$1 \mathrm{Co} 5 \mathrm{Cr}$ & 9.49 & $0.66 \pm 0.05$ & $1.30 \pm 0.11$ & $161.3 \pm 12.7$ \\
\hline
\end{tabular}

the catalysts are the same. It is reasonable to assume that the reaction on the catalysts follows a LH model, although the adsorption capability of propane and oxygen on the catalysts are quite different. Therefore, the reaction routes could be described as follows, which is similar to that reported in the literature [48].

$$
\begin{gathered}
\mathrm{C}_{3} \mathrm{H}_{8}+* \stackrel{K\left(\mathrm{C}_{3} \mathrm{H}_{8}\right)}{\longrightarrow} \mathrm{C}_{3} \mathrm{H}_{8} * \\
\mathrm{O}_{2}+2 \# \stackrel{K\left(\mathrm{O}_{2}\right)}{\longrightarrow} 2 \mathrm{O} \# \\
\mathrm{C}_{3} \mathrm{H}_{8} *+\mathrm{OH} \stackrel{k}{\longrightarrow} \mathrm{C}_{3} \mathrm{H}_{7} *+\mathrm{OH}(\mathrm{RDS}) \ldots \ldots \stackrel{+90 \#}{\longrightarrow} 3 \mathrm{CO}_{2} *+4 \mathrm{H}_{2} \mathrm{O} \# \\
\mathrm{CO}_{2} * \stackrel{\mathrm{K}\left(\mathrm{C}_{3} \mathrm{H}_{8}\right)}{\longrightarrow} \mathrm{CO}_{2}+* \\
\mathrm{H}_{2} \mathrm{O} \# \stackrel{\mathrm{K}\left(\mathrm{H}_{2} \mathrm{O}\right)}{\longrightarrow} \mathrm{H}_{2} \mathrm{O}+\#
\end{gathered}
$$

The reaction routes mainly include the following: (1) propane and oxygen adsorb non-competitively on different active sites (propane, likely on acidic $\mathrm{Cr}$ sites $\left(^{*}\right)$ and oxygen dissociation on Co sites (\#)), (Eqs. (1) and (2)); (2) the two adsorbed species react to cleave the first $\mathrm{C}-\mathrm{H}$ bond in the propane molecule, which is the RDS, and the fast sequential oxidation to form $\mathrm{CO}_{2}$ and $\mathrm{H}_{2} \mathrm{O}$ (Eq. (3)); (3) the desorption of $\mathrm{CO}_{2}$ and $\mathrm{H}_{2} \mathrm{O}$ from the catalyst surface (Eqs. (4) and (5)).

\subsection{DRIFTS investigation}

In-situ DRIFT spectroscopic studies were also performed, attempting to obtain some information on the surface species or reaction intermediates during the reaction. The $\mathrm{CrO}_{x}$ and $1 \mathrm{Co} 2 \mathrm{Cr}$ catalysts were chosen, and the results are illustrated in Fig. 10. For the $\mathrm{CrO}_{x}$ catalyst (Fig. 10(a)), several bands at 3100-3500, 2800-3000, and 2300-2400 $\mathrm{cm}^{-1}$ are observed, assigned to the surface hydroxyl groups or gaseous water, $\delta_{\mathrm{C}-\mathrm{H}}$, in the gaseous $\mathrm{C}_{3} \mathrm{H}_{8}$ and gaseous $\mathrm{CO}_{2}$, respectively. The band intensity of the gaseous $\mathrm{C}_{3} \mathrm{H}_{8}$ species $\left(2970 \mathrm{~cm}^{-1}\right)$ is relatively constant at $50-250{ }^{\circ} \mathrm{C}$, although it gradually declines at higher temperatures, which is due to its consumption owing to the reaction between $\mathrm{C}_{3} \mathrm{H}_{8}$ and $\mathrm{O}_{2}$. Accordingly, the formation of $\mathrm{CO}_{2}$ on the catalyst is initiated at $200{ }^{\circ} \mathrm{C}$, and the intensity (bands at 2300 and $2380 \mathrm{~cm}^{-1}$ ) grows at elevated temperatures. In the region of $1000-1800 \mathrm{~cm}^{-1}$, various surface carbonate species are observed. These species mainly include bi- 

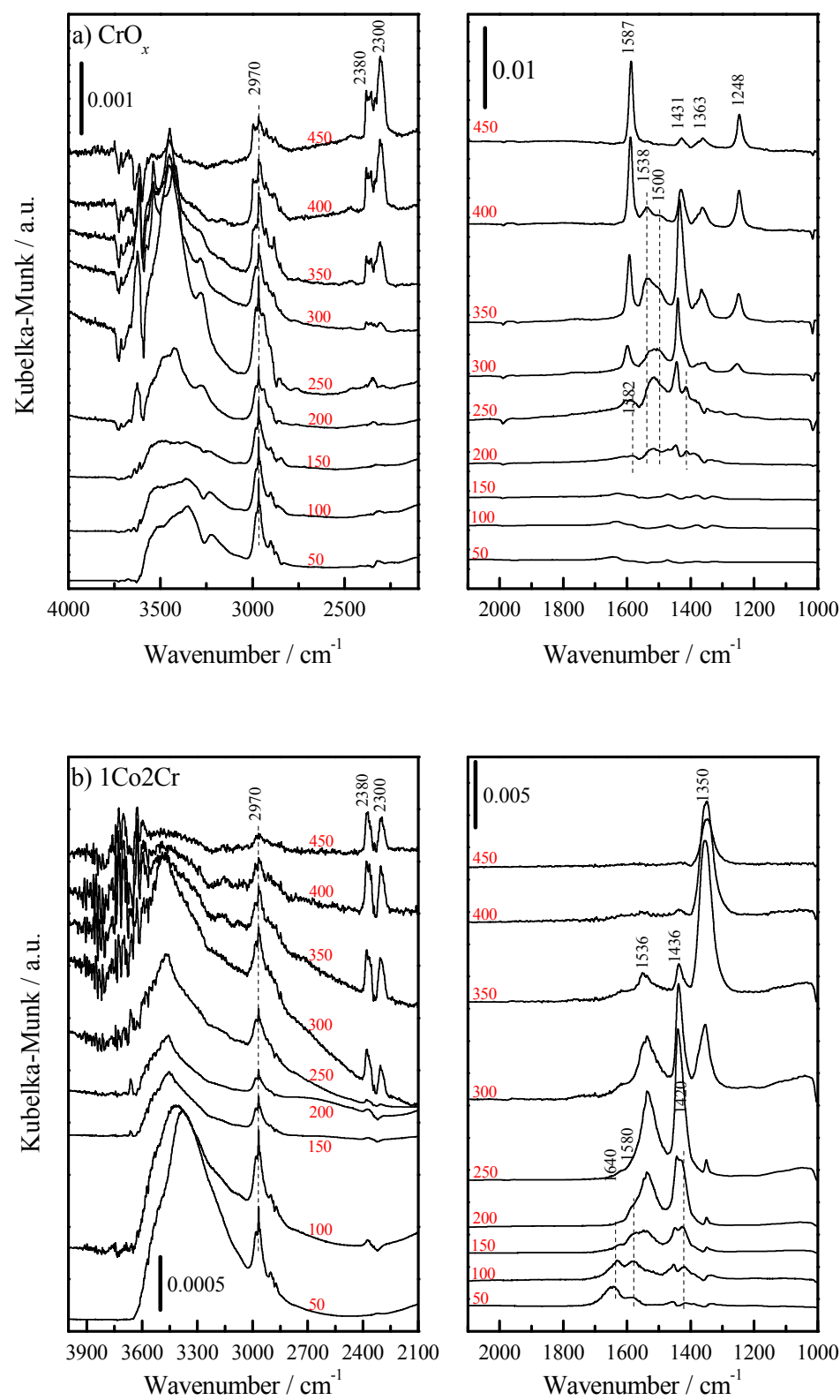

Fig. 10. In-situ DRIFT spectra of propane oxidation over the $\mathrm{CrO}_{x}(\mathrm{a})$ and $1 \mathrm{Co} 2 \mathrm{Cr}$ (b) catalysts at elevated temperatures.

dentate carbonate $\left(1587 \mathrm{~cm}^{-1}\right)$, polydentate carbonate $(1538$, 1500,1431 , and $\left.1363 \mathrm{~cm}^{-1}\right)$, and bicarbonate $\left(1248 \mathrm{~cm}^{-1}\right)$ $[52,53]$, which emerge from $200{ }^{\circ} \mathrm{C}$. It is also found that the intensities of the bidentate carbonate and bicarbonate continuously grow with increasing temperature. However, that of the polydentate carbonate reaches the maximum at $350{ }^{\circ} \mathrm{C}$ and then declines up to $450{ }^{\circ} \mathrm{C}$, indicating the decomposition of such species at high temperatures.

For the $1 \mathrm{Co} 2 \mathrm{Cr}$ catalyst (Fig. 10(b)), the band evolutions at 2100-3800 $\mathrm{cm}^{-1}$ are similar to those for $\mathrm{CrO}_{x}$ (Fig. 10(a)), which illustrates the consumption of $\mathrm{C}_{3} \mathrm{H}_{8}$ and the formation of $\mathrm{CO}_{2}$ (starts from $200{ }^{\circ} \mathrm{C}$ ). However, in the $1000-1800 \mathrm{~cm}^{-1}$ region, the bands are very different from those for $\mathrm{CrO}_{x}$. The intensity of the bidentate carbonate $\left(1580 \mathrm{~cm}^{-1}\right)$ is very weak and quickly decomposes up to $350^{\circ} \mathrm{C}$. The dominant surface carbonate is polydentate $\left(1536,1436\right.$, and $\left.1350 \mathrm{~cm}^{-1}\right)$, which could accumulate at low temperatures (up to $250{ }^{\circ} \mathrm{C}$ ) and further decompose at elevated temperatures (up to $450{ }^{\circ} \mathrm{C}$ ). The presence of polydentate carbonate on the $1 \mathrm{Co} 2 \mathrm{Cr}$ catalyst as the major species might be due to the interactions between the surface unidentate or bidentate carbonate owing to the abundant surface sites of $1 \mathrm{Co} 2 \mathrm{Cr}$ attributed to its high surface area and high surface acidity.

Therefore, the in-situ DRIFT spectra allow us to differentiate the surface species on various catalysts during the reaction, which are closely related to their surface properties. Moreover, the DRIFTS results reveal that the main surface species are various carbonates, which implies that these species might be 
the reaction intermediates and could be further decomposed to the final product $\left(\mathrm{CO}_{2}\right)$. However, other species such as $\mathrm{C}_{3} \mathrm{H}_{7}$ * (as described in the reaction mechanism, Eq. (3)) are not observed, which requires a more detailed spectroscopic investigation in the future.

\section{Conclusions}

In this work, Co-Cr-O mixed oxides with different $\mathrm{Co} / \mathrm{Cr}$ molar ratios are tested for the total oxidation of propane. The reaction behaviors are closely related to the surface properties of the mixed oxides. The $1 \mathrm{Co} 2 \mathrm{Cr}$ catalyst with a spinel structure exhibits the best performance because it has the highest surface acidity and best low-temperature reducibility, which are two crucial parameters governing the performance. The detailed kinetic investigations on some catalysts further verify that the surface acid sites may provide adsorption/activation centers for $\mathrm{C}_{3} \mathrm{H}_{8}$ molecules, while the adsorption/activation of oxygen molecules is related to the low-temperature reducibility of the catalyst. Moreover, in-situ DRIFTS results reveal the main surface species (surface carbonates) during the reaction.

\section{Acknowledgments}

This work was financially supported by the National Natural Science Foundation of China (21773212, 21872124).

\section{References}

[1] T. Garcia, B. Solsona, D. M. Murphy, K. L. Antcliff, S. H. Taylor, J. Catal., 2005, 229, 1-11.

[2] M. N. Taylor, W. Zhou, T. Garcia, B. Solsona, A. F. Carley, C. J. Kiely, S. H. Taylor, J. Catal., 2012, 285, 103-114.

[3] L. Meng, J. J. Lin, Z. Y. Pu, L. F. Luo, A. P. Jia, W. X. Huang, M. F. Luo, J. Q. Lu, Appl. Catal. B: Environ., 2012, 119-120,117-122.

[4] Y. R. Liu, X. Li, W. M. Liao, A. P. Jia, Y. J. Wang, M. F. Luo, J. Q. Lu, ACS Catal., 2019, 9, 1472-1481.

[5] J. Okal, M. Zawadzki, Appl. Catal. B: Environ., 2011, 105, 182-190.

[6] O. Sanz, J. J. Delgado, P. Navarro, G. Arzamendi, L. M. Gandia, M. Montes, Appl. Catal. B: Environ., 2011, 110, 231-237.

[7] Z. Hu, X. F. Liu, D. M. Meng, Y. Guo, Y. L. Guo, G. Z. Lu, ACS Catal,
2016, 6, 2265-2279.

[8] M. S. Avila, C. I. Vignatti, C. R. Apesteguia, T. F. Garetto, Chem. Eng. J., 2014, 241, 52-59.

[9] T. Garcia, S. Agouram, S.H. Taylor, D. Morgan, A. Dejoz, I. Vazquez, B. Solsona, Catal. Today, 2015, 254, 12-20.

[10] X. Li, Y. R. Liu, W. M. Liao, A. P. Jia, Y. J. Wang, J. Q. Lu, M. F. Luo, Appl. Surf. Sci., 2019, 475, 524-531.

[11] B. Solsona, T. Garcia, S. Agouram, G. J. Hutchings, S. H. Taylor, Appl. Catal. B: Environ., 2011, 101, 388-396.

[12] J. Y. Luo, M. Meng, Y. Q. Zha, L. H. Guo, J. Phys. Chem. C, 2008, 112, 8694-8701.

[13] M. Baldi, E. Finocchio, F. Milella, G. Busca, Appl. Catal. B: Environ., 1998, 16, 43-51.

[14] Z. Z. Zhu, G. Z. Lu, Z. G. Zhang, Y. Guo, Y. L. Guo, Y. Q. Wang, ACS Catal., 2013, 3, 1154-1164.

[15] G. Salek, P. Alphonse, P. Dufour, S. Guillemet-Fritsch, C. Tenailleau, Appl. Catal. B: Environ., 2014, 147, 1-7.

[16] Z. Ren, Z. L. Wu, W. Q. Song, W. Xiao, Y. B. Guo, J. Ding, S. L. Suib, P. X. Gao, Appl. Catal. B: Environ., 2016, 180, 150-160.

[17] Z. Hu, S. Qiu, Y. You, Y. Guo, Y. L. Guo, L. Wang, W. C. Zhan, G. Z. Lu, Appl. Catal. B: Environ., 2018, 225, 110-120.

[18] R. P. Marin, S. A. Kondrat, R. K. Pinnell, T. E. Davies, S. Golunski, J. K. Bartley, G. J. Hutchings, S. H. Taylor, Appl. Catal. B: Environ., 2013, 140-141, 671-679.

[19] B. Solsona, T. E. Davies, T. Garcia, I. Vazquez, A. Dejoz, S. H. Taylor, Appl. Catal. B: Environ., 2008, 84, 176-184.

[20] B. Solsona, T. Garcia, R. Sanchis, M. D. Soriano, M. Moreno, E. Rodriguez-Castellon, S. Agouram, A. Dejoz, J. M. Lopez Nieto, Chem. Eng. J., 2016, 290, 273-281.

[21] B. Puertolas, A. Smith, I. Vazquez, A. Dejoz, A. Moragues, T. Garcia, B. Solsona, Chem. Eng. J., 2013, 229, 547-558.

[22] P. M. Heynderickx, J. W. Thybaut, H. Poelman, D. Poelman, G. B. Marin, J. Catal., 2010, 272, 109-120.

[23] B. Faure, P. Alphonse, Appl. Catal. B: Environ., 2016, 180, 715-725.

[24] J. Chen, X. Zhang, H. Arandiyan, Y. Peng, H. Chang, J. Li, Catal. Today, 2013, 201, 12-18.

[25] Y. Wang, A. P. Jia, M. F. Luo, J. Q. Lu, Appl. Catal. B: Environ., 2015, 165, 477-486.

[26] J. D. Liu, T. T. Zhang, A. P. Jia, M. F. Luo, J. Q. Lu, Appl. Surf. Sci., 2016, 369, 58-66.

[27] H. Luo, X. Wu, D. Weng, S. Liu, R. Ran, Rare Metals., 2017, 36, 1-9.

[28] X. Wu, L. Zhang, D. Weng, S. Liu, Z. Si, J. Fan, J. Hazard. Mater., 2012, 225-226, 146-154.

\section{Graphical Abstract}

Chin. J. Catal., 2020, 41: 442-453 doi: S1872-2067(19)63480-7

Co-Cr-O mixed oxides for low-temperature total oxidation of propane: Structural effects, kinetics, and spectroscopic investigation

Wen-Min Liao, Pei-Pei Zhao, Bing-Heng Cen, Ai-Ping Jia, Ji-Qing Lu*, Meng-Fei Luo*

Zhejiang Normal University

The performance of the Co-Cr-O mixed oxides for propane combustion is related to their surface acidity and low-temperature reducibility, which account for the adsorption of propane and the activation of oxygen, respectively.

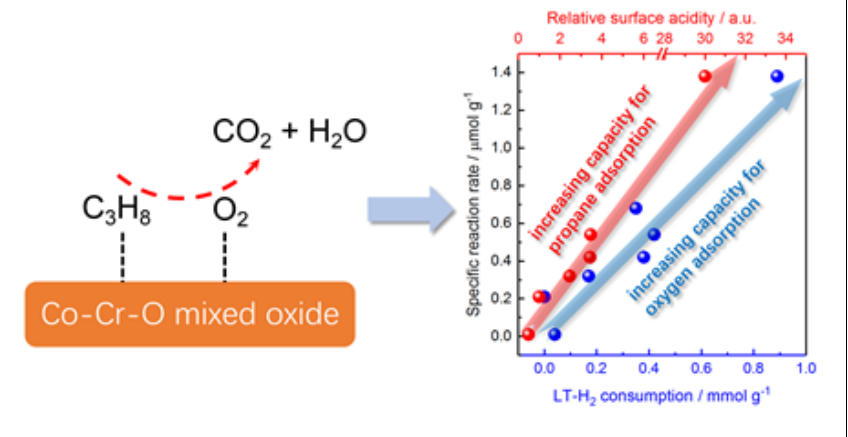


[29] T. F. Garetto, E. Rincon, C. R. Apesteguia, Appl. Catal. B: Environ., 2004, 48, 167-174.

[30] P. Bracconi, L. C. Dufour, J. Phys. Chem., 1975, 79, 2400-2405.

[31] W. Tang, W. Xiao, S. Wang, Z. Ren, J. Ding, P. X. Gao, Appl. Catal. B: Environ., 2018, 226, 585-595.

[32] C. Suchomski, C. Reitz, K. Brezesinski, C. Tavares de Sousa, M. Rohne, K. Iimura, J. P. Esteves de Araujo, T. Brezesinki, Chem. Mater., 2011, 24, 155-165.

[33] J. Chen, W. Shi, S. Yang, H. Arandiyan, D. Li, J. Phys. Chem. C, 2011, 115, 17400-17408.

[34] R. H. Ma, P. J. Hu, L. Y. Jin, Y. J. Wang, J. Q. Lu, M. F. Luo, Catal. Today, 2011, 175, 598-602.

[35] J. W. Luo, J. D. Song, W. Z. Jia, Z. Y. Pu, J. Q. Lu, M. F. Luo, Appl. Surf. Sci., 2018, 433, 904-913.

[36] J. Chen, W. Shi, X. Zhang, h. Arandiyan, D. Li, J. Li, Environ. Sci. Technol., 2011, 45, 8491-8947.

[37] C. W. Tang, C. C. Kuo, M. C. Kuo, C. B. Wang, S. H. Chien, Appl. Catal. A: Gen., 2006, 309, 37-43.

[38] B. Bai, H. Arandiyan, J. Li, Appl. Catal. B: Environ., 2013, 142-143, 677-683.

[39] W. Zhang, F. Wu, J. Li, Z. You, Appl. Surf. Sci., 2017, 411, 136-143.

[40] C. A. Chagas, E. F. de Souza, R. L. Manfro, S. M. Landi, M. M. V. M. Souza, M. Schmal, Appl. Catal. B: Environ., 2016, 182, 257-265.

[41] Y. Luo, J. Zuo, X. Feng, Q. Qian, Y. Zheng. D. Lin, B. Huang, Q. Chen,
Chem. Eng. J., 2019, 357, 395-403.

[42] X. Li, X. Li, X. Zeng, T. Zhu, Appl. Catal. A: Gen., 2019, 572, 61-70.

[43] L. F. Liotta, G. Di Carlo, G. Pantaleo, A. M. Venezia, G. Deganello, Appl. Catal. B: Environ., 2006, 66, 217-227.

[44] X. Wu, L. Zhang, D. Weng, S. Liu, Z. Si, J. Fan, J Hazard. Mater., 2012, 146, 225-226.

[45] C. F. Windisch, K. F. Ferris, G. J. Exarhos, S. K. Sharma, Thin Solid Films, 2002, 420-421, 89-99.

[46] D. C. Kim, S. K. Ihm, Environ. Sci. Technol., 2001, 35, 222-226.

[47] T. T. Zhang, J. D. Song, J. X. Chen, A. P. Jia, M. F. Luo, J. Q. Lu. Appl. Surf. Sci., 2017, 425, 1074-1081.

[48] M. P. Heynderickx, J. W. Thybaut, H. Poelman, D. Poelman, G. B. Marin, Appl. Catal. B: Environ., 2010, 95, 26-38.

[49] A. Urdă, A. Herraïz, Á. Rédey, I. C. Marcu, Catal. Commun., 2009, 10, 1651-1655.

[50] P. M. Heynderickx, J. W. Thybaut, H. Poelman, D. Poelman, G. B. Marin, Appl. Catal. B: Environ., 2009, 90, 295-306.

[51] V. Balcaen, H. Poelman, D. Poelman, G. B. Marin, J. Catal., 2011, 283(1), 75-88.

[52] O. Pozdnyakova, D. Teschner, A. Wootsch, J. Kröhnert, B. Steinhauer, H. Sauer, L. Toth, F. C. Jentoft, A. Knop-Gericke, Z. Paál, R. Schlögl, J. Catal., 2006, 237(1), 17-28.

[53] E. M. Köck, M. Kogler, T. Bielz, B. Klötzer, S. Penner, J. Phys. Chem. C, 2013, 117, 17666-17673.

\title{
Co-Cr-O复合氧化物上丙烷低温完全氧化: 结构效应、反应动力学和原位光谱研究
}

\author{
廖文敏，赵培培，岑丙横，贾爱平，鲁继青，罗孟飞” \\ 浙江师范大学物理化学研究所, 教育部先进催化材料重点实验室, 浙江金华321004
}

摘要: 低碳烷烃是一类主要的挥发性有机污染物(VOCs), 广泛生成于汽车尾气以及各种工业过程如煤处理、石油精炼以及 天然气处理等. 随着对环保要求的日益提高, 对高效VOCs消除技术的需求愈加迫切. 催化完全氧化(催化燃烧)技术具有起 燃温度低、能耗低、净化效果好(无二次污染)等优点, 因而极具应用潜力. 对于低碳烷烃的催化燃烧, 贵金属催化剂如Pt和 $\mathrm{Pd}$ 等具有很高的反应活性, 但存在价格昂贵并易中毒等缺陷限制了其商业应用. 另一方面, 过渡金属氧化物由于其价格低 廉、抗中毒性能优异及热稳定性好等特点受到广泛关注. $\mathrm{Cu}, \mathrm{Mn}, \mathrm{Co}, \mathrm{Fe}$ 等氧化物都具有良好的催化活性, 其中 $\mathrm{Co}$ 氧化物由 于其在丙烷催化燃烧中的高活性受到关注. 而在 $\mathrm{Co}$ 氧化物中添加第二金属更能促进其反应性能. 因此本文制备了一系列 不同 $\mathrm{Co} / \mathrm{Cr}$ 比例的复合氧化物用于丙烷催化燃烧, 考察了催化剂结构和表面性质对其反应行为的影响, 并通过反应动力学 和原位光谱技术对反应机理进行了探索.

实验结果表明, 随着 $\mathrm{Co} / \mathrm{Cr}$ 比例的变化, 催化剂的晶相结构、颗粒尺寸、比表面积、表面酸性以及氧化还原性等特性均 发生了明显变化, 进而影响了其反应行为. 当 $\mathrm{Co} / \mathrm{Cr}$ 比例为 $1 / 2$ 时 $(1 \mathrm{Co} 2 \mathrm{Cr})$, 催化剂为尖晶石结构并具有最大的比表面积. 该 催化剂上具有最高的反应活性 $\left(250{ }^{\circ} \mathrm{C}\right.$ 时反应速率为 $\left.1.38 \mu \mathrm{mol} \mathrm{g} \mathrm{g}^{-1}\right)$, 可归因于其最高的表面酸性和低温氧化还原性能的 协同作用. 反应动力学结果表明, $1 \mathrm{Co} 2 \mathrm{Cr}$ 催化剂上丙烷和氧气的反应级数分别为 $0.58 \pm 0.03$ 和 $0.34 \pm 0.05$, 低于 $2 \mathrm{Co} 1 \mathrm{Cr}$ (分 别为 $0.77 \pm 0.02$ 和 $0.98 \pm 0.16$ ) 和 $1 \mathrm{Co} 5 \mathrm{Cr}$ (分别为 $0.66 \pm 0.05$ 和 $1.30 \pm 0.11$ ), 表明 $1122 \mathrm{Cr}$ 催化剂相比后二者具有更高的丙烷 和氧气表面覆盖度, 得益于其更高的表面酸性和更好的低温氧化还原性能. 此外, 原位红外光谱表明, 在反应过程中, $1 \mathrm{Co} 2 \mathrm{Cr}$ 催化剂上的主要表面物种为多齿碳酸盐, 该物种在低温时 $\left(<250{ }^{\circ} \mathrm{C}\right)$ 在表面积聚, 但在高温时被分解.

关键词: 丙烷催化燃烧; Co-Cr复合氧化物; 氧化还原性能; 表面酸性; 反应动力学

收稿日期: 2019-07-07. 接受日期: 2019-08-02. 出版日期: 2020-03-05.

*通讯联系人. 电话: (0579)82287325; 传真: (0579)82282595; 电子信箱: jiqinglu@zjnu.cn

通讯联系人. 电话: (0579)82287325; 传真: (0579)82282595; 电子信箱:mengfeiluo@zjnu.cn

基金来源：国家自然科学基金(21773212,21872124).

本文的电子版全文由Elsevier出版社在ScienceDirect上出版(http://www.sciencedirect.com/science/journal/18722067). 